\title{
Engenhos e fazendas de café em Campinas (séc. XVIII- séc. XX)
}

\begin{abstract}
Áurea Pereira da Silva ${ }^{1}$
RESUMO: $\bigcirc$ artigo estuda a produção arquitetônica rural do município de Campinas legada por dois ciclos econômicos: o da cana-de-açúcar e o do café, a partir do final do século XVIII e no século XIX. Analisa a documentação historiográfica, inventários (arquivos do Centro de Memória da Unicamp) e testemunhos materiais arrolados nos levantamentos de campo. Aborda os edifícios a partir da implantação, no terreno, das diversas formas de agenciamento (no caso da produção cafeeira, a disposição dos edifícios determinada pelo fluxo das operações e tarefas de beneficiamento do grão) e dos múltiplos programas necessários ao setor produtivo e às habitações. Enfatiza a questão tecnológica dos edifícios, revelando a preferência pelos métodos e materiais tradicionais da cultura arquitetônica paulista, particularizada no domínio da taipa de pilão e da taipa de mão até a chegada da ferrovia, na década de 1870.

PALAVRAS-CHAVE: Arquitetura. Engenhos. Fazenda de café. Século XVIII. Século XIX. Campinas.
\end{abstract}

ABSTRACT: The article studies the architectural country side of the city of Campinas, a legacy of two economic cycles: the sugar cane and coffee industries at the end of the 18th century and during the 19th century. It analyses the historic documentation and files found in the Centro de Memória Unicamp. It is about the buildings and their construction, the different forms of negotiating and the multiple programs necessary to the growing and housing sectors (during the coffee cycle, the disposition of the buildings determined by the flowing of the operations and needs related to the seed betterment). The article also gives emphasis to technological details of the buildings, revealing preference for traditional methods and materials used in the architectural culture in São Paulo state. This particularity is shown by the domain of mud huts until the advent of railroad in 1870.

KEYWORDS: Architecture. Mills. Plantation ranch. 18th Century. 19th Century. Campinas.

município de Campinas é fruto da admirável expansão portuguesa em demanda dos Sertões de Goiás. Com o intuito de estabelecer a ligação entre essas áreas auríferas e São Paulo, foi aberto, por volta de 1725, o conhecido
1. Docente da Faculdade de Arquitetura e Urbanismo da Pontifícia Universidade Católica de Campinas E-mail: psaurea @uol.com.br 
2. Esta pesquisa é parte do inventário intitulado Fazendas Campineiras levantamento arquitetônico, realizado entre 1993 e 1995 junto à $\mathrm{Fa}$ culdade de Arquitetura e Urbanismo da Pontifícia Universidade Católica de Campinas, e contou com a valiosa colaboração dos auxiliares de pesquisa: Eleusina Lavôr Holanda de Freitas, Débora San ches, Alessanda Spagnol, Marise Vitale Cardoso, Ana Paula Cairrão e Pedro Paulo Mainieri, responsáveis pela documentação fotográfica apresentada. Os créditos de autoria das fotos são dados à equipe. caminho dos guaiases, que atravessava a região no sentido norte. À beira desta estrada pipocaram pousos, sesmarias, bairros rurais, engenhos e a modesta freguesia de Nossa Senhora da Conceição das Campinas de Mato Dentro. Verificamos que boa parte do valioso patrimônio arquitetônico rural campineiro concentrou-se, inicialmente, nestas terras vermelho-escuras da região norte. Ao final dos setecentos, a cana crescia bem em todo município, tornando o açúcar o produto mais importante. Por volta de 1830, o plantio do café foi ensaiado com êxito e os fazendeiros iniciaram a substituição dos canaviais pelos cafezais. Sai de cena o engenho e entra a fazenda de café. Reconstituir a memória dessas antigas sedes de propriedade, com seus espaços de morar e trabalhar, com suas antigas construções, recuperar os agentes econômicos e sociais envolvidos nestas produções, durante o último quartel dos setecentos e todo oitocentos, foram os desafios assumidos neste artigo².

Para a reconstituição dos aspectos concretos do patrimônio arquitetônico rural campineiro, inventariamos 31 propriedades. As informações arroladas resultaram em plantas, desenhos, fotos e no estudo da tipologia funcional, do partido arquitetônico, dos materiais e técnicas construtivas e da linguagem formal das construções preservadas em cada ciclo econômico. Em busca do perfil das propriedades e proprietários, valemo-nos da leitura dos inventários post-mortem.

Em relação à pesquisa sobre a história de Campinas, as informações vieram de diferentes fontes: dos relatos e diários dos viajantes, dos memorialistas e cronistas, dos almanaques; e da recente historiografia local, produzida, sobretudo, pelos pesquisadores da Unicamp, criadores do Centro de Memória da mesma universidade.

A arquitetura dos engenhos

$\bigcirc$ engenheiro português Luiz D'Alincourt, passando pela vila de Campinas a caminho de Cuiabá, em 1818, descreve:

Todo o terreno de Campinas é ótimo para a plantação de cana; de maneira que, há doze anos a esta parte, tem se conhecido um aumento considerável na exportação do açúcar. $\bigcirc$ lugar chamado Anhumas tem a primazia entre os mais para a dita plantação; basta dizerse que, a perto de sessenta anos, que recebe a planta, sem que tenha sido preciso deixarse o terreno em descanso, por se não conhecer o menor abatimento na produção [...] Há no termo desta Vila sessenta engenhos, contando os do fabrico de aguardente; quinze dos quais são movidos por água; e outros muitos se podem levantar por esta maneira cômoda. O principal senhor de engenho é o Coronel de Milícias Luiz Antônio, morador em São Paulo, homem ajudado pela fortuna de um modo espantoso, e que possui uma das mais sólidas casas do Brasil; só ele, em Campinas, tem dezesseis engenhos, um dos quais the rendeu em 1817 nove contos de réis; a sua colheita anual não desce de trinta mil arrobas de açúcar, e a renda da sua casa anda em oitenta mil cruzados. Além desta, existem outras de bons fundos. A do Coronel Francisco Antônio de Souza anda de dez, a doze mil arrobas, em cinco engenhos, quatro dos quais são próprios. A do Sargento Mor Floriano de Camargo 
Penteado chega a oito mil arrobas em dois engenhos. A do Capitão Theodoro Ferrás Leite, de três a quatro mil; e outras muitas deste lote: de maneira que se podem regular vinte engenhos a três mil arrobas cada um (ALINCOURT, 1953, p. 53).

Cinco anos mais tarde, o viajante inglês Edmund Pink encontrou "terrenos bem arborizados e plantações de cana-de-açúcar e algumas poucas de café, geralmente bem irrigados e admiravelmente muito apropriados para o cultivo desses artigos [...] em torno de 70 fazendas de açúcar [...]" e uma vila com uma população estimada de "5000 a 6000 pessoas" (SEVCENKO; MINDLIN, 2000, p. 87-89).

A cana-de-açúcar continuou progredindo em Campinas até 1836, registrando nesse ano seus níveis mais elevados de produção: 93 engenhos de açúcar e 93 destilarias de cachaça ${ }^{3}$. A partir daí, os números começaram a decrescer, chegando, em 1854, a apenas 44 engenhos. Com a chegada do café, essa atividade passa para segundo plano. Embora tornando-se economicamente inexpressivo, o açúcar irá conviver com o início da atividade cafeicultora, uma vez que o retorno do investimento inicial na produção de café era demorado. O convívio do açúcar e do café deve ter sido algo normal na região durante décadas.

engenho de açúcar, ou qualquer outra propriedade, podia ser formado com terras obtidas por sesmarias, por posse, por herança ou por aquisição. Em Campinas, as dimensões das sesmarias variavam bastante: podiam ter meia légua ou uma légua de testada por três de fundo ("de sertão", como se dizia), ou meia légua de quadra; sua localização, a partir dos documentos, resulta problemática. Como bem observou Pupo (1983), há incorreção na nomenclatura dos locais, impropriedade dos marcos limítrofes das glebas e incertezas quanto às reais dimensões das terras doadas. No início, os engenhos concentraram-se preferencialmente na direção Campinas-Moji-Mirim, no "bairro rural" de Atibaia, fazendo muitas vezes testada com a estrada de Goiás ${ }^{4}$, e nas direções de Jundiaí e ltu. A rede fundiária campineira esteve sempre em constantes transformações. Herança, dotes, vendas de parcelas, compras fragmentaram e aglutinaram, inicialmente, os engenhos e, mais tarde, as fazendas de cafés

A cultura do açúcar marca a entrada da lavoura comercial na Província de São Paulo. Terra, até então, de poucos escravos, ela criava, agora, uma demanda por mão-de-obra africana. Nesta região, como nas demais da Colônia, dentro das condições da época, o escravo era peça indispensável ao desenvolvimento da cultura canavieira. $\bigcirc$ aumento do número de escravos, em Campinas, pode ser acompanhado por meio da leitura dos inventários: 23 escravos na fazenda Mato Dentro, 181 1; 41 escravos no inventário de Alexandre Barbosa de Almeida, 18227; 54 escravos no inventário de Antônio Cerqueira César, 18228; 160 escravos no inventário de Paula Joaquina Andrade, 1830, assim distribuídos: Fazenda Duas Pontes: 70; Engenho Ponte Alta: 36; Engenho São Bento: 18; Engenho Sertão: 17; Sítio da Caxoeira [sic]: 19. O viajante francês Saint-Hilaire (1972, p. 132) observou, em 1819: "As propriedades consideradas, na época de minha viagem, como tendo alguma importância, possuíam, pelo menos, uns vinte escravos [...]". Nos "maços de população" de
3. Cifras retiradas de Petrone (1968, p. 48). Ver também, nessa página, o quadro da produção de açúcar em Campinas, de 1775 a 1854 .

4. Esse caminho, conhecido como "dos Guaiases", foi aberto entre $1722 \mathrm{e}$ 1725, e fazia a ligação entre São Paulo e as áreas de mineração de Goiás e Mato Grosso.

5. Para a consulta dos nomes dos primeiros proprietários de engenho, ver Pupo $(1983$, p. 119157).

6. Centro de Memória da Unicamp - TJC, cx. 8, pasta 249, Campinas.

7. Centro de Memória da Unicamp - TJC, cx. 26, pasta 719, Campinas.

8. Centro de Memória da Unicamp - TJC, cx. 24, pasta 658 , Campinas.

9. Centro de Memória da Unicamp - TJC, cx. 51, pasta 1322, Campinas. 
10. Centro de Memória da Unicamp - TJC, cx. 8 , pasta 249, Campinas

11. Centro de Memória da Unicamp - TJC, cx. 24 pasta 658, Campinas.
Campinas, conservados no Arquivo do Estado, há dados referentes à escravaria nos engenhos locais no ano de 1816: "o número variava desde um escravo até 83, a média por fazenda orçava em torno de 24. Mais tarde, em 1834, a média de escravo por fazenda seria de 37. Fazendas com mais de 100 escravos não eram raras" (PETRONE, 1968, p. 113).

O açúcar atraiu, ainda, outro personagem, o mineiro. Exauridas as minas, a população mineira afluiu às regiões economicamente atraentes da Província de São Paulo. Muitos vieram para as zonas canavieiras de ltu e Campinas, marcando com suas presenças os hábitos e a arquitetura local.

Ao açúcar, São Carlos - primeiro nome de Campinas - deve sua origem como vila (1797) e como cidade (1842). O produto modificou o panorama econômico e social da região, criou novas estruturas viárias, desenvolveu o comércio e formou a primeira elite agrária local: os donos de engenho formavam a principal classe da terra. $\bigcirc$ ser engenheiro - nomenclatura dada ao proprietário de engenho -, como mais tarde o ser fazendeiro de café, inseria a pessoa na classe dominante. Para D'Alincourt (1953), eles eram "homens assaz polidos, e de agradável trato". Moravam na fazenda com a família e os agregados, administrando-a. Pink (SEVCENKO; MINDLIN, 2000, p. 87) observou que eles possuíam na vila "casas respeitáveis, que ocupavam apenas durante os domingos ou outros feriados [...]", e elas eram "de taipa e muitas das janelas são envidraçadas". Seus hábitos e modos de vida eram simples, e o dinheiro do açúcar permitiu um pouco mais de conforto. Alguém certa vez disse que "a doçura do açúcar e o seu comércio amaciaram os costumes do país e reduziram à civilização os seus habitantes".

Saint-Hilaire (1972, p. 131 -33), visitando a cidade de Campinas em 1819 , em plena época açucareira, descreve o seu desenvolvimento e assinala alguns traços civilizadores dessa nova sociedade:

As suas ruas não são muito largas e suas casas são novas, unidas umas às outras, cobertas de telhas, e construídas, em sua maioria, com terra socada. Algumas delas podem ser consideradas muito bonitas. A igreja paroquial, pequena e mesquinha, eleva-se numa praça que forma um longo quadrado. Quando de minha viagem, era intensa, nessa localidade, a construção de casas, sendo por aí fácil de perceber que a mesma, em pouco tempo, adquiriria notável importância.

A julgar pelos móveis e objetos arrolados nos inventários selecionados para amostragem, as sedes de engenhos não ostentavam nenhuma opulência: "dois catres, uma caxa abaulada com fexadura, dois pares de canastras velhas e um contador velho" (Engenho Mato Dentro, 181 1) 10. E, também:

uma cama de vento com armação [...] trez camas sem armação com seu colxão de xitta, trez redes azuis em bom uzo e com suas varandas, cinco moxos com assentos de taboa com algum uso, huma caxa grande com oito e meio palmos de comprido com ferragem e bom uzo, duas caxas iguais [...] com dez palmos cada huma de comprido sem ferragem e quase nova, huma ditta maior sem ferragem, hum par de canastras [...] encouradas com couro [...] com sua ferragem com fexadura e xave novas, hum par de canastras [...] outro par de canastras [...]" [inventário de Antônio Cerqueira César, 1822]"1. 
E ainda são arrolados como "peças de casa":

um bofeta grande de bom uzo, outro dito menor em bom uzo, outro dito novo com gavetas, outro dito inferior sem gaveta, um armário novo com xave, uma caixa grande nova, outra dita grande mais uzada com fexadura, duas canastras descubertas sem ferragem alguma, quatro catres tecidos de couro em bom uzo, um banco grande com goarda adiante em bom uzo, outro dito mais inferior, dez moxos cubertos de couro em bom uzo [...] um oratório com uma Imagem do Senhor Cruscificado e mais imagem miúda [...] jarros e castiçais em prata [inventário de Alexandre Barbosa de Almeida, 1822] ${ }^{12}$; hum faqueiro completo, onze libras e 93 oitavos de pratas, todos os preparos do altar [listados com "prata em obras"] [(Fazenda Duas Pontes, 1830 $]^{13}$.

fato de esse ciclo econômico ter sido de curta duração, três quartos de século no máximo, e ter sido substituído rapidamente pelo café, levou alguns historiadores a considerarem inexistente qualquer traço dessa cultura na paisagem rural campineira. Realmente, à primeira vista nada restou. Não há, na região inventariada, vestígio de engenhos, entendidos aqui como locais de produção. A raridade de dados e a inexistência material das instalações e equipamentos tornam o processo de conhecimento dessa cultura bastante problemático. Ao contrário desta região açucareira, outras tiveram melhor sorte quanto à preservação de engenhos e de registros iconográficos, a exemplo do que ocorreu no Nordeste, no Litoral Norte paulista, e na vizinha região de ltu.

Diante dessas constatações, procuramos orientar a pesquisa em duas direções: para a análise das fontes documentais e para a análise das evidências materiais arroladas durante o trabalho de campo.

Assim, o documento encontrado no Departamento do Arquivo do Estado, pela historiadora Maria Thereza Scherer Petrone (1968, p. 229), impõese como peça fundamental. Trata-se do contrato de construção de um engenho em Campinas, firmado no ano de 1815 entre o proprietário e o carpinteiro:

Digo eu Felizardo, José Róis que tenho justo e tratado com o Sr. Capm Custodio Mel Alz a factura de um engenho d'ágoa para moer canas e fazer assucar bem feito, acabado obra forte tudo a respeito de perfeição na forma do costume tudo a minha custa a saber feitio tirada e condução de todas as madeiras nessas para a dita obra e sustento, finalmente a por completo tudo que abaixo se declara sendo o mmo Sr. Capm Custodio obro a dar cipos covas buracos e ajuda a aplumar os esteios; a levantar telhas, a dar dois carreiros pa puxar as madeiras, bois, carros, carretão, arreios e cordas, moitões, ferragem, pregos, ripas: arripar, barrear. A obra q justou he a sege: Uma casa pa Engenho de tacanissa de 75 pal $^{14}$ de comprido e 44 de largo, duas porteiras de duas folhas cada uma e esta casa do Engenho baldramada em roda com parapeito de madeira lavrada: um lanço de 30 ps de cumprido e 44 de largo e 5 lanssos no alinhamento de engenho, de 22 ps de comprido, todos com a largura de 44 ps. Tacanissa nos otons barroteados em todos seus baldrames pr q o mmo Sr. Cap. fara tape em lugar e a sua custa: 5 janelas na frente e 2 no otão rasgados, balaustres pr baixo e uma folha de janela em cada uma das de cima: um corredor de todo o cumprimento dos 6 lanssos e largura de 22 ps mais ou menos com uma porta e 3 janelas um puxado para cobres de 40 ps de cumprido e 30 de largo com uma porta e 2 janelas, - Tendal do cumprimto dos 5 lanssos, assoalhado de taboas furadas pa formas de barro com todas as beias nessas pa estas de pao rolisso. Um sobradinho de 20 ps de cumprido
12. Centro de Memória da Unicamp - TJC, cx. 26, pasta 719 , Campinas.

13. Centro de Memória da Unicamp - TJC, cx. 51, pasta 1322, Campinas.

14. 1 pal $=1$ palmo $=$ $0,22 \mathrm{~m}$ 
15. Dos termos citados, cabem algumas explicações: tacaniça, nome atribuído às peças de madeira do telhado, que vão da cumeeira até os fre chais apoiados nos cunhais; nos telhados de quatro águas e planta retangular, as tacaniças formam as duas vertentes do plano triangular; baldra me (no texto "baldramada"), viga de madeira disposta horizontalmente sobre os alicerces ou encaixada nos esteios verticais; barrote (no texto "barroteados"), viga de madeira de seção quadrada usada no vigamento do soalho e no forro; $b a$ laústre, cada pequena coluna, pilar ou ripa de uma série que se une na parte superior por um parapeito, corrimão etc.; $o i$ tão (no texto "otons", "otão"), cada uma das paredes que formam as fachadas laterais da cons trução, triângulo de parede sobre as fachadas laterais que fecha o espaço entre a cumeeira, as terças e os contrafrechais da armação do telhado. e 12 de largo com parapeito em roda: uma porta pa o Engenho, a escada de taboa, duas escadas de taboas pa o tendal. Roda, Bolandeira, Rodete, moendas tudo de cabreuva com caixão na roda, apejador e as beias necessas para isto. O Sr. capitão Custodio dara todas as telhas necessas pa a obra. Me obrigo mais a fazer um moinho no $\mathrm{q}^{\prime}$ respeita some a capintaria, dandoseme o mais tudo pronto $[\ldots]^{15}$.

À primeira constatação, trata-se de um engenho organizado a partir de um conjunto de edifícios espacialmente caracterizados segundo suas funções, a saber: a casa do engenho, o tendal, o puxado dos cobres e um sobradinho. Pela descrição, a casa do engenho, local onde se processava a moagem da cana, seria retangular, medindo $16,50 \mathrm{~m}$ por $9,68 \mathrm{~m}$ (75 palmos por 44 palmos), erguida sobre baldrame com parapeito de madeira lavrada e fechada por duas porteiras. Seguindo o alinhamento do engenho e com a mesma largura, abremse dois espaços: o primeiro com 6,60m de comprimento (30 palmos) e o segundo, reservado ao tendal - local onde se processava a purga, a purificação ou o clareamento do açúcar - medindo 24,20m (5 lanços de 22 palmos). Pela descrição, esses espaços seriam divididos ao meio, em toda a sua extensão, por um corredor, ficando determinado que a área do tendal seria soalhada, com tábuas furadas para o assentamento das formas de barro - os pães de açúcar, recipientes de forma cônica onde se colocava o melado para decantar as impurezas e solidificar os cristais de açúcar. $\bigcirc$ puxado dos "cobres", espaço reservado às fornalhas e ao cozimento da garapa, teria $6,60 \mathrm{~m}$ por $4,40 \mathrm{~m}$, uma porta e duas janelas. Para concluir, o contrato determinava a construção de um sobradinho de $4,40 \mathrm{~m}$ por $2,64 \mathrm{~m}$, ligado diretamente ao engenho por uma escada e ao tendal por duas, todas feitas de tábua. As referências "baldrame", "barrotes", "barrear", "cipós" e "esteios" apontam para a técnica do pau-a-pique. Os lanços ("lanssos") indicam a série de cômodos, certamente perpendiculares à cumeeira, "no alinhamento do engenho". Trata-se de um "engenho d'ágoa", movido a energia hidráulica, construído em madeira, com roda, bolandeira, rodete, moendas, peças da engenharia mecânica que, à roda-d'água, sempre disposta verticalmente, acoplavam outras rodas dentadas; a menor era chamada "rodete" (vertical) e a maior, a "bolandeira", era disposta horizontalmente. $\bigcirc$ eixo vertical da bolandeira transmitia o movimento às moendas. A importância da madeira na construção dos equipamentos distinguia a figura do carpinteiro no contexto do engenho. Seu trabalho tinha de ser bem executado, senão o engenho não funcionava, como determinava o contrato: "factura de um engenho d'ágoa [...] bem feito, acabado, obra forte tudo a respeito de perfeição".

A autora citada devemos também a transcrição do trecho de um inventário de 1844, de Campinas, mostrando o engenho em seu aspecto mais global:

Pelo sítio com casa de morar em bom estado, sendo parte della forrada e assoalhada com um oratório e altar para celebrar missa, casa de enfermaria, de ferreiro, de carpintaria, paiol, senzalas, moinho, pilões de roda de ralar mandioca, engenho de moer cana de cilindros com abundância de água para todas as máquinas, 6 carros com seus pertences, 
1 caixão de açúcar, 4 gavetas de secar açúcar, duas pipas, de gastalhos, 2 alambiques grandes, 5 caldeiras, 88 formas de taboa, uma porção de copos de azedar e outros para mel e garapa, esfriadeiras, espumadeiras, sendo uma velha e 4 que servem, 2 punhais e mais utensílios existentes pertencentes às referidas máquinas [...] (PETRONE, 1968, p. 102).
16. Centro de Memória da Unicamp - TJC, cx. 24, pasta $658 ;$ TJC,cx. 81 ,pasta 1937 ; TJC, cx. 51 , pasta 1322, Campinas.

A residência evidencia um cuidado na fatura e no acabamento, e testemunha a presença "de um oratório e altar", sorte de capela doméstica, peça rara na arquitetura rural da região. Quanto ao engenho, ele aparece descrito como movido a força hidráulica e precursor no uso das moendas horizontais "com muitas terras e grande produção [...] à margem direita do rio Atibaia [...] aí fora instalado o primeiro engenho deitado [...]". Os "cobres" arrolados (tachos, caldeiras, alambiques, escumadeiras) indicam a presença dos equipamentos importantes e caros à montagem de um engenho.

$\bigcirc$ conjunto descrito é formado por vários edifícios, definindo um layout de partido aberto, no dizer de Luis Saia, com construções independentes: casa de moradia, casa de enfermaria, de ferreiro, de carpintaria, paiol, senzalas e o engenho d'água. Trata-se de um importante engenho movido a água e com maquinismo horizontal para a moagem de cana por meio de cilindros de ferro (conhecidos como deitados). Para Petrone (1968), esses dois procedimentos tecnológicos encareciam a montagem do engenho, pois, segundo ela nos informa, um engenho d'água em Campinas, em 18 15, chegava a custar $900 \$ 000$ réis. $\bigcirc$ alto preço restringiu seu uso, pelo menos nas primeiras décadas do século XIX, como testemunha D'Alincourt (1953), em 1818 : dos sessenta engenhos existentes em Campinas, 45 eram movidos por animais e quinze pela água. Nos inventários pesquisados, encontramos "engenho d'agoa" (nos inventários de Antônio Cerqueira César, 1822, e de Manoela Joaquina Oliveira, 1838 I e "um engenho de bois" (Fazenda Duas Pontes, 1830)16.

Da mesma maneira como essas poucas informações foram garimpadas na historiografia, pudemos identificar, no patrimônio rural preservado (Figura 1), certos vestígios arquitetônicos da época; eles permanecem no esquema de implantação da sede, nas habitações - residência e senzala - e nos poucos edifícios do setor produtivo que resistiram à chegada do café.

$\bigcirc$ antigo engenho de Atibaia, denominado posteriormente Fazenda Fazendinha (Figura 2), que pertenceu ao brigadeiro Luís Antônio de Sousa, conserva, do período, um grande quadrilátero com pátio central erguido em taipa de pilão e pau-a-pique (Figura 3). Embora desativado e posteriormente adaptado à cultura do café (e hoje abandonado), é possível identificar nesses espaços parte do programa de necessidades do antigo engenho: o tendal na parte soalhada, a senzala na ala de pé-direito menor, e as fornalhas no amplo espaço oposto à porta de entrada. Fora do quadrilátero, ficavam o engenho propriamente dito, com as moendas e a residência principal; somente esta última chegaria até nós (Figura 4). Embora muito modificada na época do café, quando teve duplicada sua área construída, ainda é possível reconhecer a antiga moradia na construção que ocupa toda a ala direita, que conserva a planta original em L e o esquema de organização espacial interno típico da arquitetura açucareira, que, na fachada frontal, dispunha as salas sociais; no miolo da casa, as alcovas 


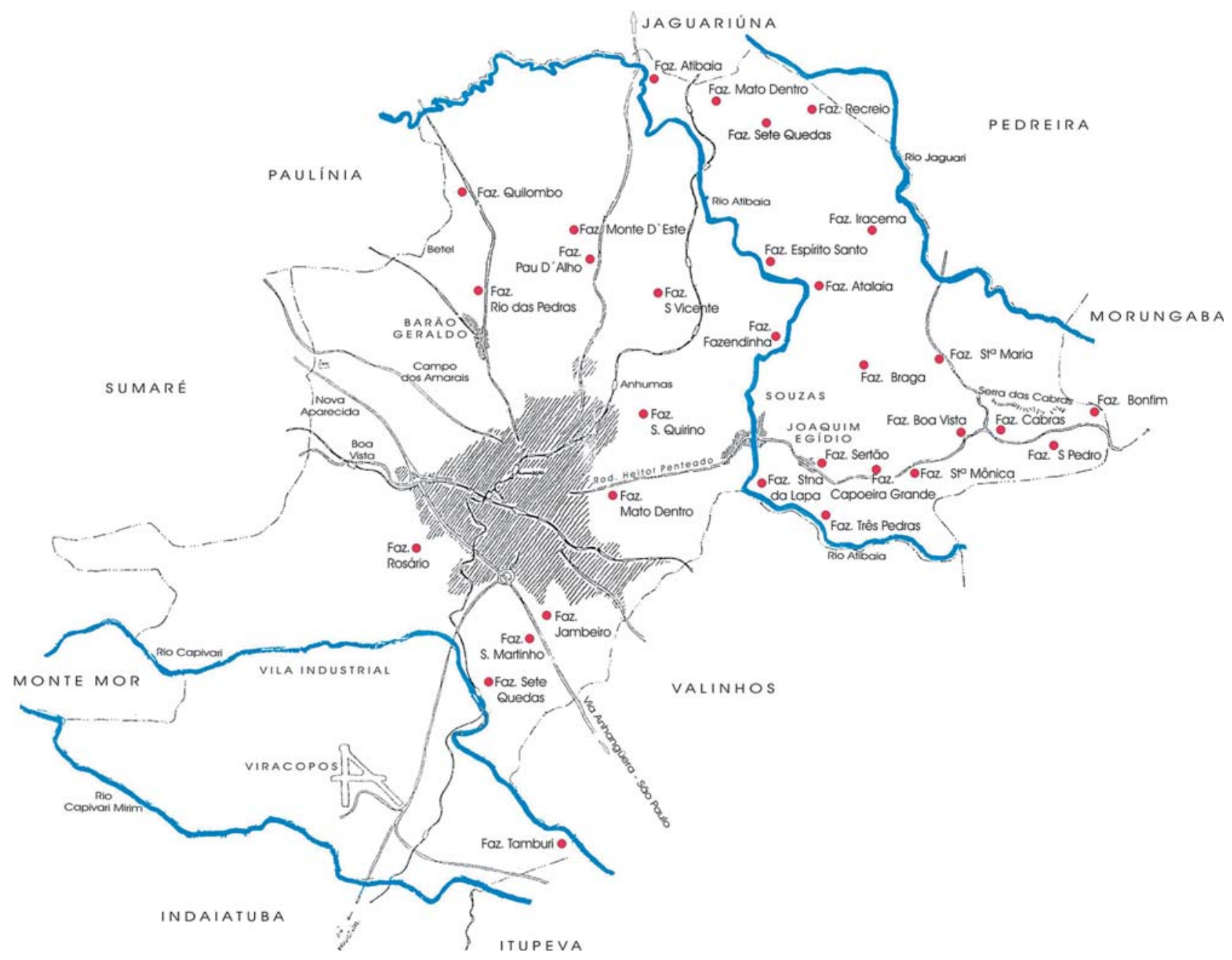

Figura 1 - Mapa de localização das fazendas inventariadas da região de Campinas. Redesenho do original do arquivo do Condephaat.

e os quartos; na parte posterior, a varanda ou sala de jantar; deixando, na parte alongada do L, em uma espécie de puxado, a área de serviço. A julgar pelas suas dimensões, essa ala poderia acomodar outras funções além das atividades estritamente domésticas. Com a construção da nova moradia, apoiada tecnicamente na parede lateral preexistente, surgiram duas residências, que tiveram suas fachadas unificadas a partir da inserção do alpendre frontal, que dá acesso ao pavimento nobre. As alterações na planta (originalmente em L transformada posteriormente em E) acabaram gerando espaços duplos e complexos. Este importante exemplar da primeira metade do século XIX, mostra com nitidez a preferência pela implantação em meia encosta, que aproveitava o desnível do terreno para erguer a fachada frontal, tornando-a assobradada. A parte posterior, embora profundamente alterada, apresenta-se, na ala direita, 


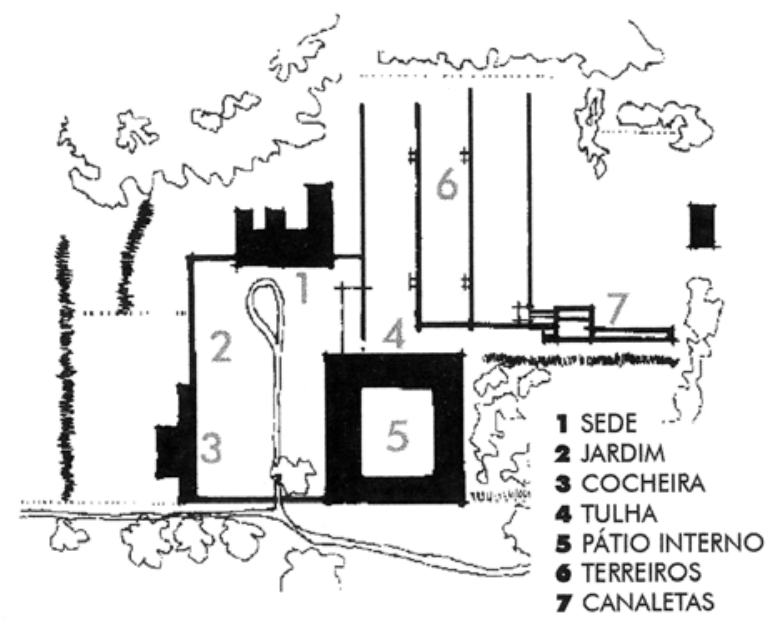

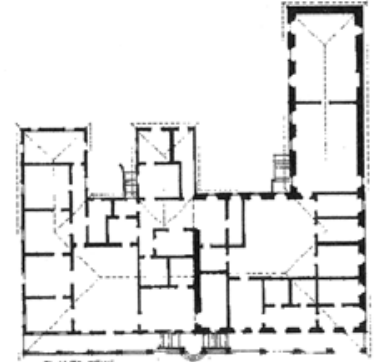

PLANTA SEDE

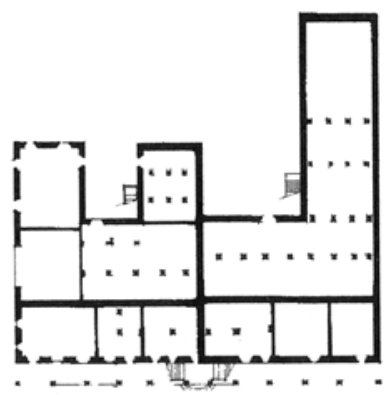

PLANTA PORÃO

\section{IMPLANTAÇÃO}

Figura 2 - Fazenda Fazendinha. A ala direita da residência e o edifício quadrilátero são da época do engenho (início do século XIX). A duplicação da sede, os terreiros com canaletas são acréscimos do período do café. A planta original em L transformou-se em três corpos acoplados ao retângulo principal, determinando uma cobertura de onze águas. Redesenho dos originais do arquivo do Condephaat.

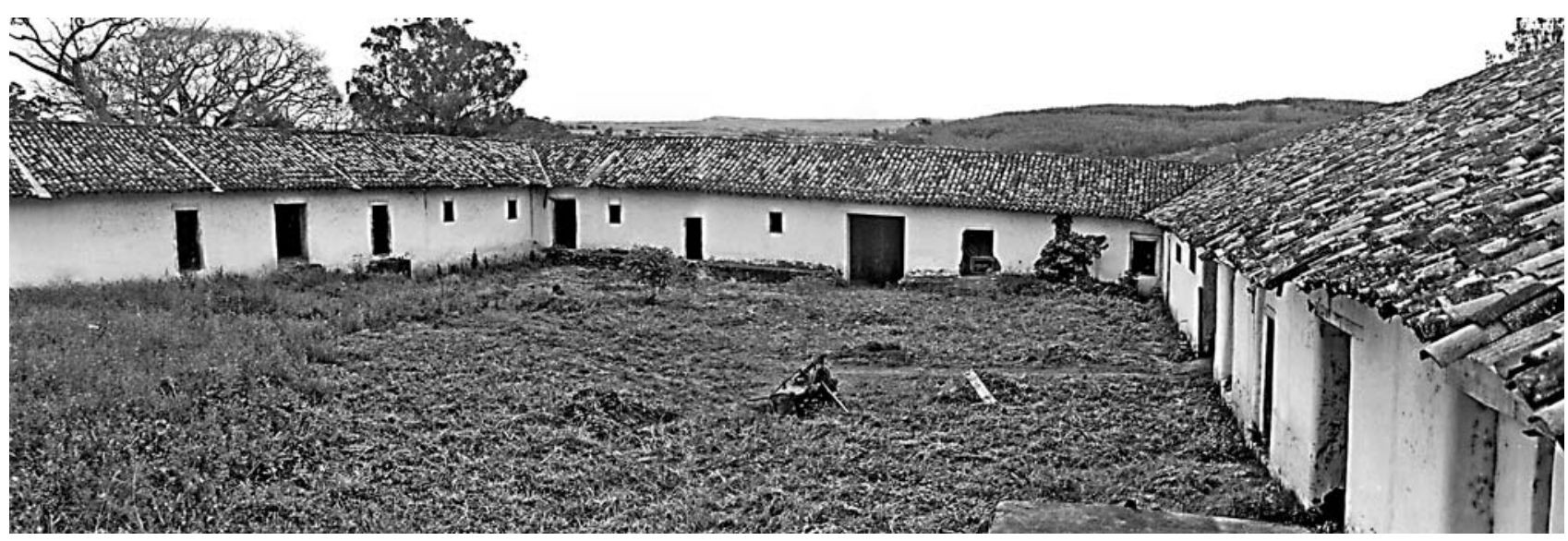

Figura 3 - Fazenda Fazendinha. Grande quadrilátero com pátio central da época do engenho, erguido em taipa de pilão e taipa de mão, sobre embasamento de pedra. A senzala ficava na ala de menor pé-direito, as fornalhas no amplo espaço oposto à porta de entrada e o tendal na parte soalhada à esquerda. Esta última foi transformada posteriormente em tulha para café. Fotografia da equipe.

com dois pisos; e térrea na ala esquerda. Assim, todo o rés-do-chão forma um vasto porão de pé-direito irregular, cujos cômodos serviam de depósito. Convém notar que esse espaço não se comunicava internamente com o pavimento superior.

Os dois exemplares descritos a seguir são casas de sobrado, implantadas em terrenos quase planos, cujo pavimento superior assenta-se 
17. A documentação iconográfica dessas sedes pode ser vista no texto de Pupo (1983), nas Figuras $214,224,225,227$

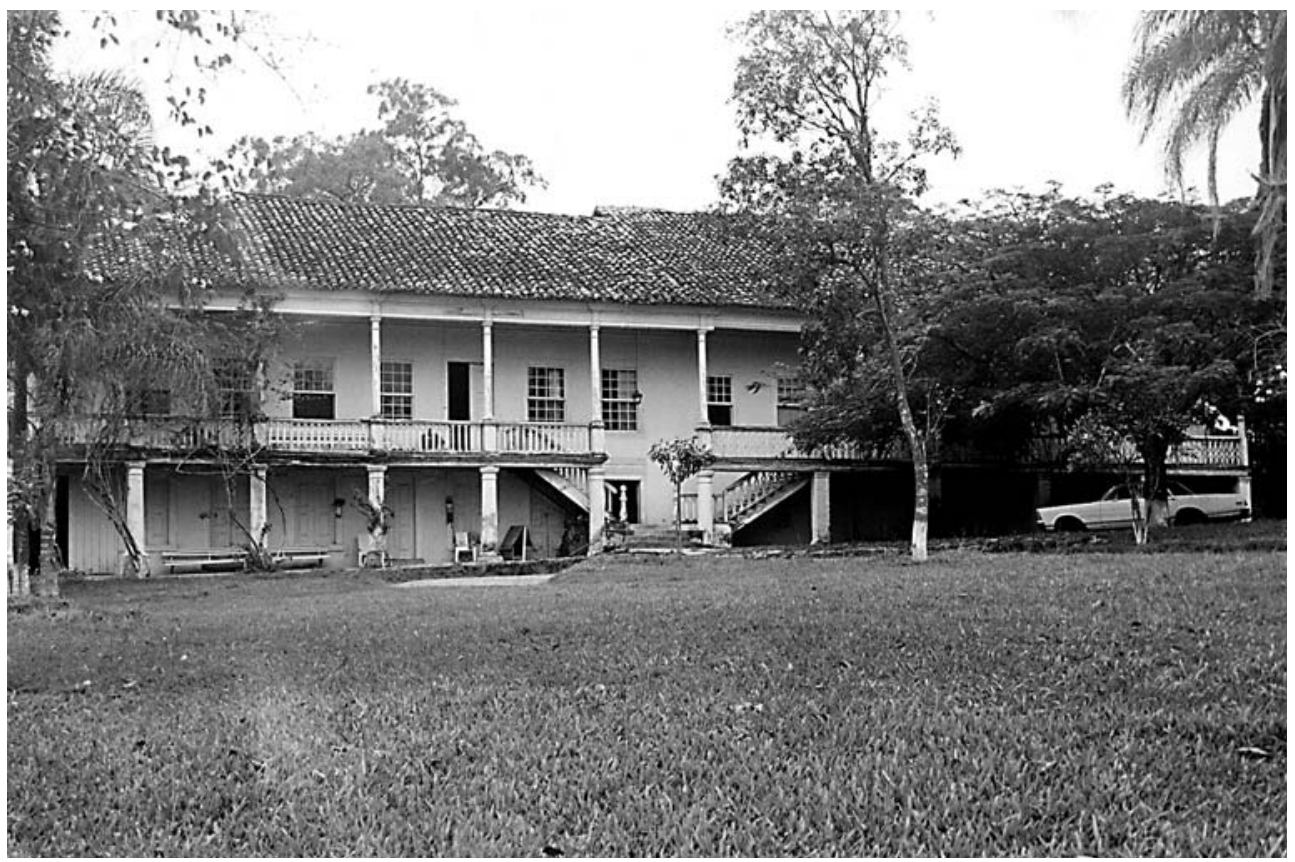

Figura 4 - Fazenda Fazendinha. Residência assobradada de valor excepcional, resultante de duas edificações: a mais antiga localiza-se na ala direita e foi estruturada em taipa de pilão, com divisórias em taipa de mão. Foi usada como apoio técnico da segunda casa. $\bigcirc$ alpendre e as águas unificam a fachada. Fotografia da equipe.

integralmente sobre o piso térreo. A novidade, agora, reside no tratamento regular do alçado do pé-direito do térreo destinado a depósito. Ao que parece, a preferência pela implantação da casa sobre um terreno plano e o uso do embasamento uniforme sob toda a construção foi um procedimento corrente na arquitetura mais antiga da região, como ilustra a iconografia selecionada por Pupo (1983), representando as sedes de antigos engenhos, hoje, infelizmente, destruídas ${ }^{17}$. Nestas preciosas imagens, é oportuno observar que o acesso principal às moradias foi resolvido de duas maneiras: (1) a partir do piso inferior interligado internamente, por meio de uma escada, ao pavimento superior; e (2) mediante uma escada externa terminada em patamar e conectada com o piso superior.

Voltemos aos exemplares investigados. A residência da Fazenda Mato Dentro, localizada no atual Parque Ecológico, que pertenceu ao tenente-coronel Joaquim Aranha Barreto de Camargo, conserva fundações e paredes remanescentes do período da cana (Figura 5). Erguidas em taipa de pilão e pedra entaipada, elas formam as paredes externas e internas estruturais do pavimento inferior, sobre as quais se assenta a moradia do período do café.

Implantação semelhante pode ser observada nas fotos e nas ruínas da sede do antigo Engenho Quilombo, também de propriedade do brigadeiro Luís Antônio de Sousa (Figura 6). Assentado sobre um terreno plano, o edifício tinha todo o embasamento construído em taipa de pilão, definindo a presença 

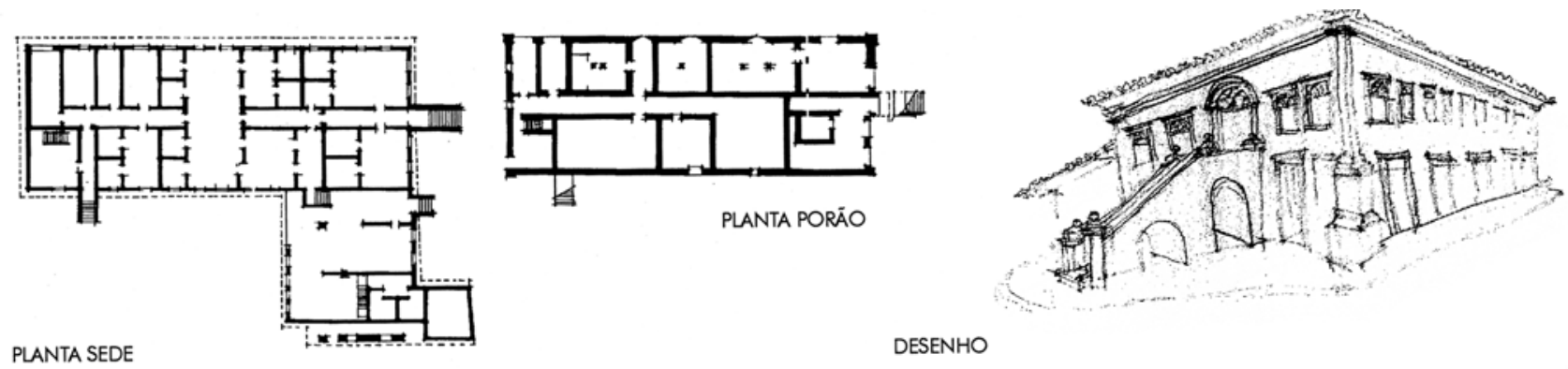

DESENHO

Figura 5 - Engenho Mato Dentro. Fundado por Joaquim Aranha de Camargo (início do século XIX). Residência em planta retangular organizada simetricamente em torno de um corredor central, dispondo a varanda (sala de jantar) no centro da casa. Do período do engenho, permanecem as fundações e as paredes estruturais do piso térreo em vários tipos de taipa: pedra entaipada, enxaimel, taipa de pilão e taipa de mão. Acesso frontal através de pequeno patamar. Redesenho dos originais do arquivo do Condephaat.

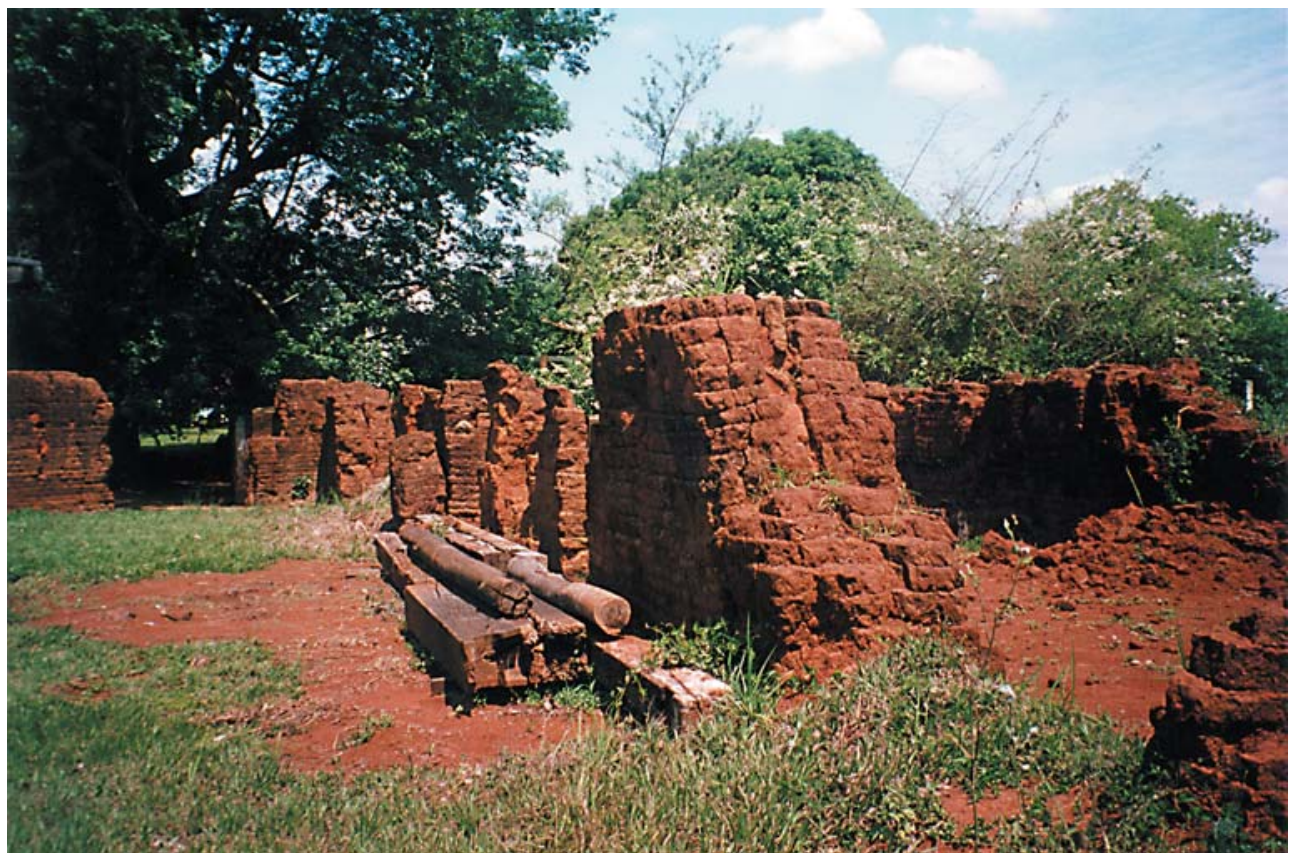

Figura 6 - Engenho Quilombo. Ruínas das paredes de taipa de pilão do embasamento do porão da antiga residência (primeiro quartel do século XIX). Fotografia da equipe.

de um amplo porão de altura homogênea, sobre o qual se ergueu o pavimento do sobrado em paredes externas de taipa de pilão, e pau-a-pique nas divisórias.

A adoção da solução construtiva firmada na taipa de pilão impôs às residências severidade e rigidez. Aí não há lugar para ornatos e nem mesmo para o alpendre, elemento característico da arquitetura da segunda metade dos oitocentos, como veremos. Quanto às plantas, a sede da Fazenda Mato Dentro 
circunscreve-se em um prisma retangular (o anexo lateral é posterior) e a do Engenho Quilombo, em um corpo originalmente em forma de L, que, segundo o proprietário atual, tinha os quartos alojados na ala lateral, fora do corpo principal, e a cozinha em um puxado inserido na fachada posterior. A soma desses espaços resultava em uma estranha planta em $T$ invertido.

Merecem ainda destaque duas construções remanescentes do antigo Engenho Mato Dentro do Jaguari - atual Fazenda Santa Rita do Mato Dentro, localizada no bairro rural de Carlos Gomes - (Figura 7), a saber: uma casa térrea (transformada posteriormente em depósito) e um sobrado, ambos erguidos em taipa de pilão, cujas paredes têm espessura média de $70 \mathrm{~cm}$. Pupo (1983) sugere ter sido o edifício térreo a primeira residência construída por Alexandre

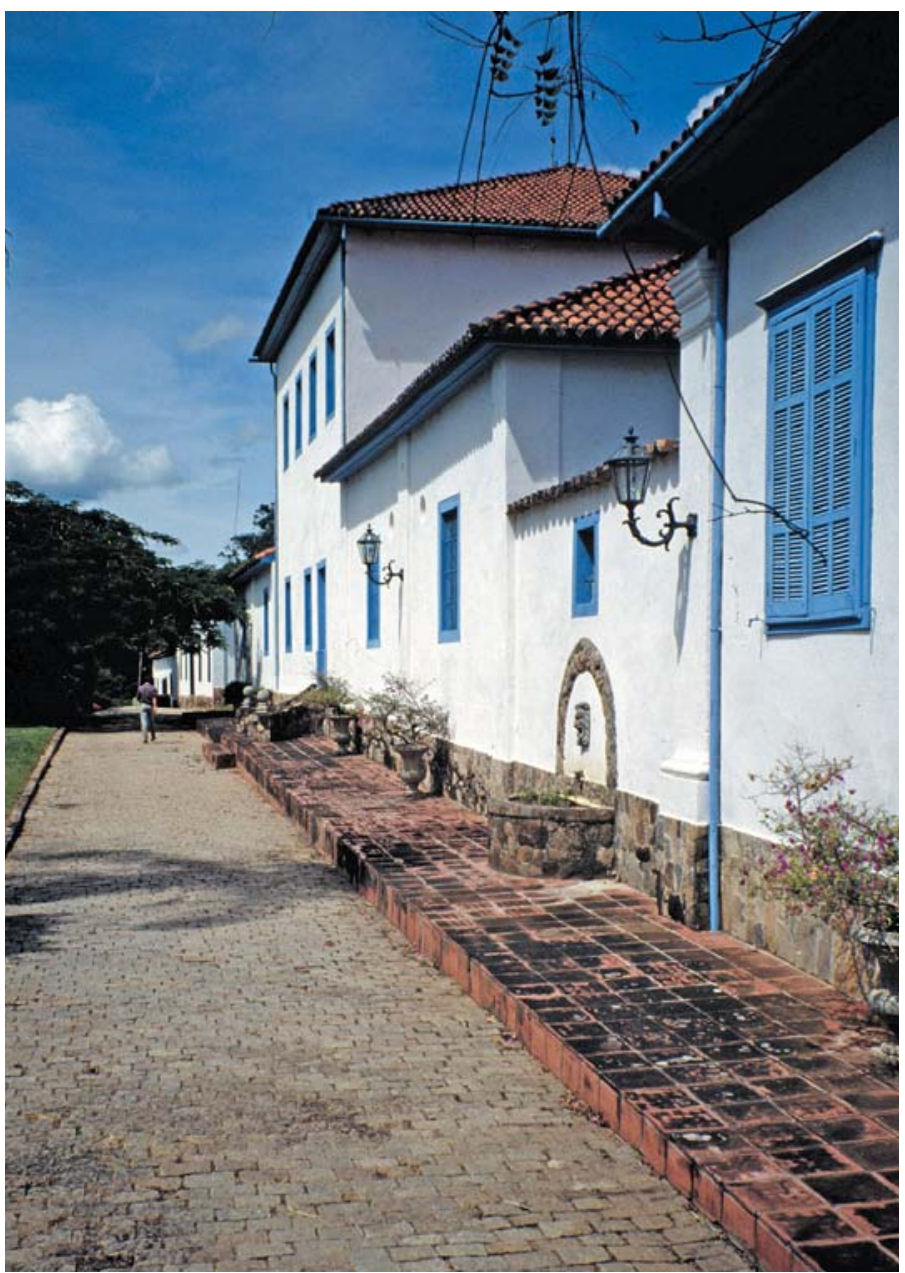

Figura 7 - Engenho Mato Dentro (Jaguari). Depósito e sobrado (primeiro quartel do século XIX), dispostos linearmente na declividade do terreno, erguidos em taipa de pilão. Para Mello Pupo, o depósito seria a primeira residência de Alexandre Barbosa de Almeida lantigo sesmeiro). Fotografia da equipe. 
Barbosa de Almeida, sesmeiro dessas terras desde 1800. No seu inventário de $1822^{18}$, foram arrolados: "uma morada de cazas de vivenda no sitio [...] cazas de fabricar assucar (duas cazas de engenho com suas moendas e de purgar [...] um sobrado para caza de assucar $[\ldots]^{\prime \prime}$.

A casa térrea sede de engenho pode ser analisada emblematicamente no exemplar conservado na antiga Chácara Proença, cujas terras pertenceram à primeira sesmaria da Freguesia das Campinas do Mato Grosso e estão hoje inseridas no tecido urbano campineiro. Trata-se de uma casa construída no final do primeiro quartel dos oitocentos, implantada numa espécie de platô, com pequeno desnível (frente-fundo), erguida em técnica mista (taipa de pilão e taipa de mão), onde se evidencia a tradição mineira de afastar o soalho do contato direto com a terra. A planta em $\mathrm{L}$ segue a tipologia tradicional dos espaços segregados, dispondo os serviços na parte alongada (hoje, demolida). Além da moradia, esse espaço conserva ainda uma construção retangular em taipa de pilão, sem divisórias, bastante apropriada às possíveis funções a ela atribuídas: de pouso real, de engenho e de tulha (armazém).

Por fim, é necessário mencionar a presença de alguns edifícios isolados, erguidos também em taipa de pilão, cobertos por telhados de quatro águas, remanescentes dos antigos engenhos Sertão e Capoeira Grande. Se do ponto de vista arquitetônico esses edifícios guardam algum interesse, são, entretanto, incapazes de traduzir e informar o programa a que originalmente se destinavam.

Parece-nos relevante conhecer que as antigas sedes dos engenhos conservaram-se como habitações após a chegada do café. Preservadas parcialmente, elas sofreram inúmeras intervenções e alterações advindas dos novos hábitos da cultura cafeeira. Esse fato explica, em parte, o reduzido número de exemplares genuinamente ligados à cultura do açúcar e as dificuldades de análise dos edifícios conservados. Apesar disso, é possível constatar a presença de algumas recorrências nessas construções, particularmente no que se refere à preferência: pelos sistemas construtivos tradicionais, taipa de pilão e taipa de mão; pela presença de dois partidos de implantação, sobre terreno plano e à meia encosta, gerando respectivamente a casa de sobrado e a moradia assobradada. Numericamente superiores, as casas assobradadas representavam um progresso em relação às tipologias tradicionais, que exigiam: terrenos planos, sólidas fundações de paredes entaipadas, e volumes compactos. Assim, do ponto de vista técnico, as residências assobradadas implantadas em meia encosta adaptaram-se com mais facilidade às irregularidades da topografia local e ao emprego das técnicas mistas - das taipas - em voga desde o final dos setecentos. Ao que parece, esta casa assobradada chega à região por influência mineira, que também destinava o nível inferior - o porão - ao uso como depósito. 
Fazenda de café e sua arquitetura

A quem viaja pelos sertões do noroeste paulista empolga o espetáculo da preamar do café. A onda verde nasceu humilde em terras fluminenses. Tomou vulto, desbordou para São Paulo e fraldejando a Mantiqueira, veio morrer, detida pela frialdade do clima, à orilha da Paulicéia. Mas não parou [...] foi espraiar-se em Campinas [...] Veio sorrir, ali, ao pisar esse Oásis [...] que é - Oeste paulista. E arranchou de vez, para sempre em sua casa.

Monteiro Lobato, A onda verde.

No mesmo ano de 1836, que registrou o apogeu da produção açucareira de Campinas, o café já aparecia cultivado em nove fazendas. Introduzido no começo do século, por iniciativa de alguns fazendeiros, ele fechará a primeira metade do século XIX como o produto mais importante. Ernani da Silva Bruno ${ }^{19}$ sintetiza com cifras essa expansão: 89 fazendas produzindo 200 mil arrobas em 1852; 177 fazendas com uma produção de 335 mil arrobas e 6 mil escravos em 1854. Zaluar (1975, p. 137) informa que, no ano de 1860, quando de sua viagem a Campinas, existiam "1 89 fazendas de café, contra vinte fazendas de cana com seus respectivos engenhos".

A rápida substituição dos canaviais por cafezais pode ser explicada por uma série de fatores internos e externos. Toda aquela infra-estrutura criada pela cana agora assegurava condições favoráveis à implantação do café: estocagem de mão-de-obra escrava, acumulação de capital, abertura de estradas para o escoamento agrícola, experiência nos transportes e na comercialização etc. As condições do mercado externo, ávido de café e saturado de açúcar, também the eram favoráveis. Afora essas e outras razões, o café dava lucro. Em 1842, quando a vila de São Carlos retoma o antigo nome de Campinas e é elevada à categoria de cidade, ela estava às vésperas de se tornar a maior produtora de café do mercado internacional.

Os progressos e o desenvolvimento da cidade no início da segunda metade do século XIX foram testemunhados e descritos entusiasticamente por Zaluar (1975, p. 137-141):

Há na cidade sessenta e quatro lojas de fazendas e ferragens, vinte armazéns de gêneros de fora, e cento e dez tavernas, o que tudo paga direitos à municipalidade. Além destas, há três fábricas de licores, duas de cerveja, uma de velas de cera, uma de chapéus, três hotéis, duas casas de bilhares, diversas lojas de alfaiates, sapateiros, latoeiros, torneiros, marceneiros, seleiros, armadores, quatro padarias, uma fábrica de charutos, três relojoeiros, três ourives, três retratistas em daguerreótipo e um a óleo, três pintores hábeis, e uma tipografia, onde se publica o Conservador [...] $\bigcirc$ teatro de Campinas, melhor do que o da capital, faz honra ao bom gosto e à riqueza da população [...] A instrução pública tem tido em Campinas um desenvolvimento não menos satisfatório do que a lavoura [...].

Nosso informante cita as escolas existentes, esclarece que "a maior parte dos fazendeiros paga a mestres para educar seus filhos", e ainda fornece 
o quadro populacional do município: 24 mil habitantes, sendo 14 mil escravos e 10 mil livres.

A expansão cafeeira veio acompanhada do aumento da mão-de-obra escrava, que até 1850 foi abundante. Nesses meados do século, por pressão dos altos preços (um cativo chegava a custar de dois a três contos de réis) e por pressões abolicionistas, alguns fazendeiros vanguardistas iniciaram a substituição do escravo pelo imigrante, ensaiando sistemas de parcerias ou - como o visconde de Indaiatuba, em 1854, na Fazenda Sete Quedas - criando os primeiros núcleos de colonos.

Empacando, literalmente, o desenvolvimento futuro da cidade e a expansão cafeeira estavam os meios de transportes, que ofereciam precárias comunicações com Jundiaí, São Paulo e o porto de Santos. No lombo dos burros, viajavam gentes e mercadorias.

Otrem chegou em 1872, com a Companhia Paulista de Estrada de Ferro ligando Campinas a Jundiaí, completando, com esse trecho, a interligação com Santos, agora transformado em porto de escoamento do café produzido no Velho Oeste paulista. Também em 1872, nascia, em Campinas, a Companhia Mogiana, com o intuito de estabelecer a ligação com Moji-Mirim e atingindo posteriormente as divisas com Minas Gerais. Assim, a partir da década de 1870, o município assistiu à extraordinária expansão das ferrovias, com a criação de uma teia de troncos e ramais que, no dizer de Sérgio Milliet, iam "atrás do café ou por vezes à sua frente, constituindo verdadeiras estradas catacafé" (MILLIET, 1982; MATOS, 1973, p. 47). Um bom exemplo desse sistema, foi o ramal ligando Campinas a Jaguariúna, traçado pela Companhia Mogiana, com suas estações - Anhumas, Tanquinho, Desembargador Furtado e Carlos Gomes - projetadas próximas às fazendas locais. Convém ressaltar que o grande desenvolvimento das companhias Paulista e Mogiana foi realizado com capital levantado entre os cafeicultores por meio de ações. Os homens ligados ao café foram os agentes que fundaram, financiaram e geriram tais empresas.

Em sintonia com a riqueza gerada pelo café, a cidade de Campinas projetava-se como importante pólo de atividades empresariais, comerciais, centro de serviços e destacado núcleo cultural. Índice particularmente significativo das últimas décadas do Império foi o aumento das instituições educacionais, dos jornais, dos clubes associativos, dos profissionais liberais, das fábricas e dos estrangeiros.

Resta ver como os frutos dessa aliança inseparável - café, ferrovia e aceleração da vida urbana - foram responsáveis pelas mudanças materiais nas fazendas e pela alteração nos hábitos e na mentalidade do campo.

Como observou Sérgio Buarque de Holanda (1973, p. 130), a monocultura do café,

simplificando [...] a produção, aumentou [...] a necessidade do recurso aos centros urbanos distribuidores dos mantimentos, que outrora se criavam no próprio lugar. O resultado é que o domínio agrário deixa, aos poucos, de ser uma baronia, para se aproximar, em muitos de seus aspectos, de um centro de exploração industrial [...] $\bigcirc$ fazendeiro que se forma ao seu contato, torna-se, no fundo, um tipo citadino, mais do que rural, e [...] para quem a 
propriedade agrícola constitui, em primeiro plano, meio de vida e só ocasionalmente local de residência ou recreio. As receitas de bem produzir não se herdam pela tradição e pelo convívio, através de gerações sucessivas, com as terras de plantio, mas são aprendidas, por vezes, nas escolas e nos livros.

Esse ser bipolarizado tem casa ou palacete na cidade, investe em atividades urbanas, da mesma maneira que remodela a residência rural e investe na modernização dos equipamentos e na melhoria da produção agrícola; alguns ostentam títulos nobiliárquicos agraciados pelo Império, outros se engajam na construção do regime republicano, e todos participam da grande transformação econômica da Província.

Apesar de o sistema escravista perpetuar métodos antiquados de produção e beneficiamento de café, é a partir de meados do século XIX que os fazendeiros tomam conhecimento das vantagens da mecanização e das técnicas chamadas "mais civilizadas", empregadas nas múltiplas operações de beneficiamento do café: lavagem, secagem, despolpamento, ventilação, escolha, cotação e classificação. Os almanaques de Campinas e da Província de São Paulo estampam constantes listas de fabricantes e importadores de máquinas agrícolas. Também os jornais campineiros anunciam modernas máquinas fabricadas pelas firmas Lidgerwood, Bierremback, Muller, Mac Hardy, Irmãos Faber, Sampaio Peixoto, entre outros, como mostra a Gazeta de Campinas de 17 de março de 1870:

Aos senhores fazendeiros: Bierremback \& Irmãos acabam de fundar no Largo de Santa Cruz, desta cidade, uma oficina a vapor para a fábrica de máquinas de Beneficiar Café por um sistema aperfeiçoado, simples e mui sólido. As máquinas compõem-se de Descascador, Ventiladores e Separadores, tudo perfeitamente acabado, e feito das melhores madeiras do país. Fabricam-se de diversos tamanhos, desde as máquinas que beneficiam 50 arrobas até 400 arrobas por dia; são montadas nas fazendas por conta dos fabricantes. Entre outras vantagens sobre toda e qualquer máquina de beneficiar café, têm estas a de precisarem muito pouca força, não terem peças de fácil desarranjo e difícil reparo; assim como aproveitarem mais café do que qualquer outra. Os preços são muito reduzidos (MARTINS, 1990, p. 491.

Convém, agora, analisar o pólo gerador dessa riqueza: a fazenda.

A fazenda de café é um complexo que abrange as terras reservadas ao cafezal, às matas e a outros cultivos; as instalações de beneficiamento do café; e as habitações. Na sua organização, influem o tamanho da propriedade e as técnicas agrícolas adotadas. É certo que, desde o primeiro quartel do século XIX, os fazendeiros puderam dispor de literatura agrária, tanto de origem estrangeira como nacional, organizada como uma espécie de manual informativo, capaz de orientá-los na escolha do sítio, no tipo de solo, na instalação e organização de futuras fazendas. Provavelmente, a primeira publicação de teor técnico foi a obra de Laborie, O fazendeiro de café na ilha de São Domingos, traduzida em 1799; o interesse pelo assunto levou os brasileiros a também escreverem seus manuais ${ }^{20}$. Neles predomina o senso prático no tratamento dos temas, como ilustra o bom conselho, dado aos futuros cafeicultores, de 
condicionarem a escolha do sítio à presença de boas matas e boa "aguada". De fato, em todas as fazendas estudadas há farta disponibilidade de água, que era considerada elemento necessário e indispensável às múltiplas tarefas: como fonte de energia hidráulica, acionando máquinas, movendo rodas; como fonte de abastecimento; e, sobretudo, como elemento fundamental e prático às operações de terreiro, ou seja, de lavagem e transporte dos grãos através dos tanques e canaletas.

Assim sendo, a escolha do sítio apropriado e a proximidade da água sempre foram fatores determinantes na implantação de uma fazenda. Quanto às formas de agenciamento das instalações, isto é, o layout dos edifícios no espaço reservado, observa-se uma certa racionalidade na localização dos prédios, determinada pelo fluxo das operações e tarefas de beneficiamento do café. Também os edifícios tiveram que se adequar aos diversos programas: beneficiamento, armazenamento, habitação etc. Tudo isso somado acabou definindo o próprio partido arquitetônico da fazenda.

Sendo a fazenda de café um conjunto formado de inúmeras edificações e tendo em vista a documentação inventariada, parece-nos relevante focalizá-la sob duas óticas: como conjunto e como arquitetura de edifícios isolados.

Pode-se dizer que as fazendas de Campinas, a exemplo do que ocorrera naquelas do Vale do Paraíba, organizaram o conjunto das edificações em quadra, com uma diferença: nelas, o tipo de agenciamento não foi estruturado de forma tão compacta e regular como naquelas do vale paraibano, cujo esquema foi fartamente documentado nas pinturas de Georg Grimm e José de Lima, e nos preciosos desenhos de implantação das sedes executados pelo arquiteto Antônio Luiz de Andrade (1973, 1976-). Podemos inferir que as formas irregulares, em Campinas, derivaram das antigas implantações herdadas dos engenhos, que predeterminaram o esquema do futuro agenciamento das fazendas. Observando que, em geral, sobretudo a partir de 1870, o aumento da produção de café criou a necessidade de ampliar a área dos terreiros. No primeiro momento, eles foram agregados aos já existentes, mas, quando o café atingiu índices elevados de produção, novos terreiros foram construídos fora do perímetro original da sede. Isso explicaria, também, a irregularidade da quadra e a pulverização do conjunto.

Por maior que seja o número de variáveis, é possível destacar dois tipos básicos de agenciamento do conjunto nas fazendas campineiras. $\bigcirc$ primeiro é dominado pelo espaço dos terreiros, que distribui e organiza as edificações, cabendo à residência uma posição de destaque, como nas fazendas São Joaquim (Figura 8), Bonfim (Figura 9), Braga, São Pedro, Sertão etc. Às vezes, algumas construções ficaram fora do quadrilátero, como as colônias, por serem mais recentes, a exemplo de Três Pedras, Rio das Pedras e Iracema (Figura 10). 0 segundo grupo mostra o terreiro deslocado do conjunto, como nas fazendas Cabras (Figura 1 1), São Vicente, Roseira, Fazendinha, Sete Quedas (Figura 12) e Jambeiro.

Finalmente, há que se mencionar a presença marcante dos muros de taipa de pilão cercando os limites das sedes cafeeiras, com o objetivo de 


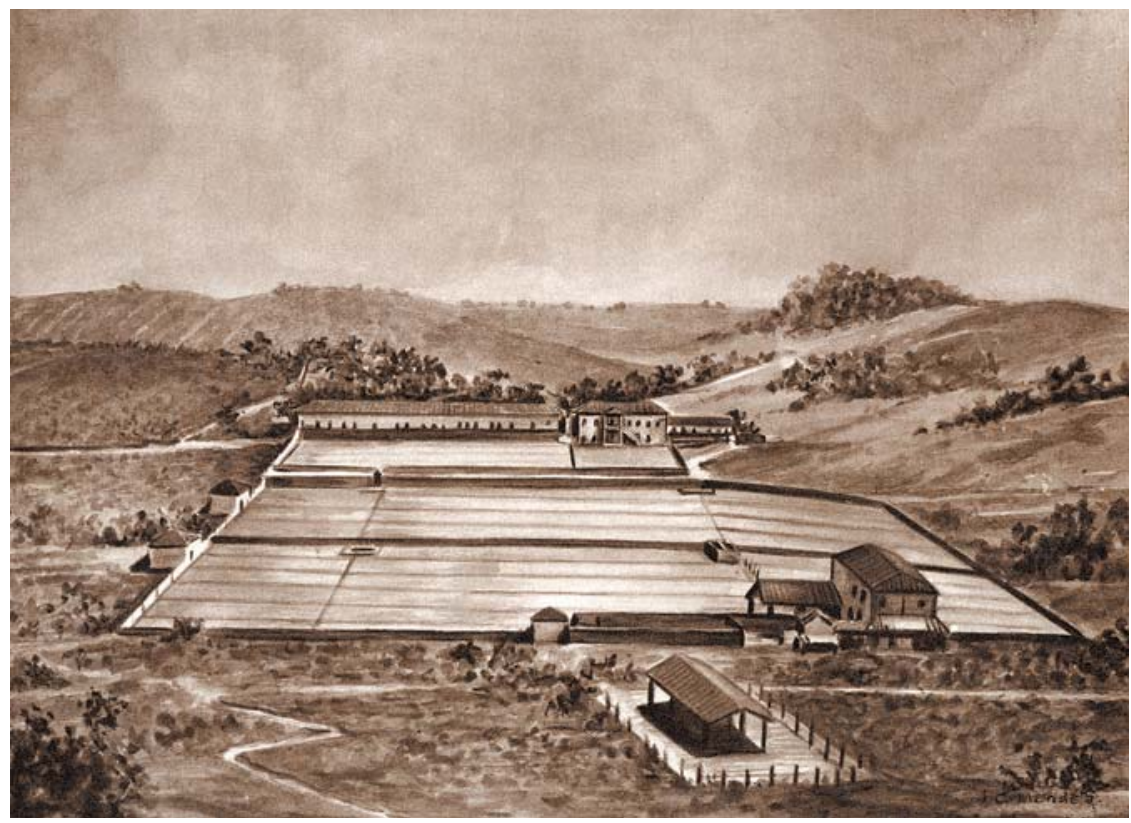

Figura 8 - Fazenda São Joaquim. Fazenda de café implantada em quadra com terreiro central agenciando o conjunto: na parte superior, localizam-se residência e senzala e, no lado oposto, casa de máquinas e tulha. Terreiro equipado com tanques e canaletas. Muro de taipa de pilão cercando todo o espaço. José de Castro Mendes, aquarela, s.d. (MENDES, 1947).

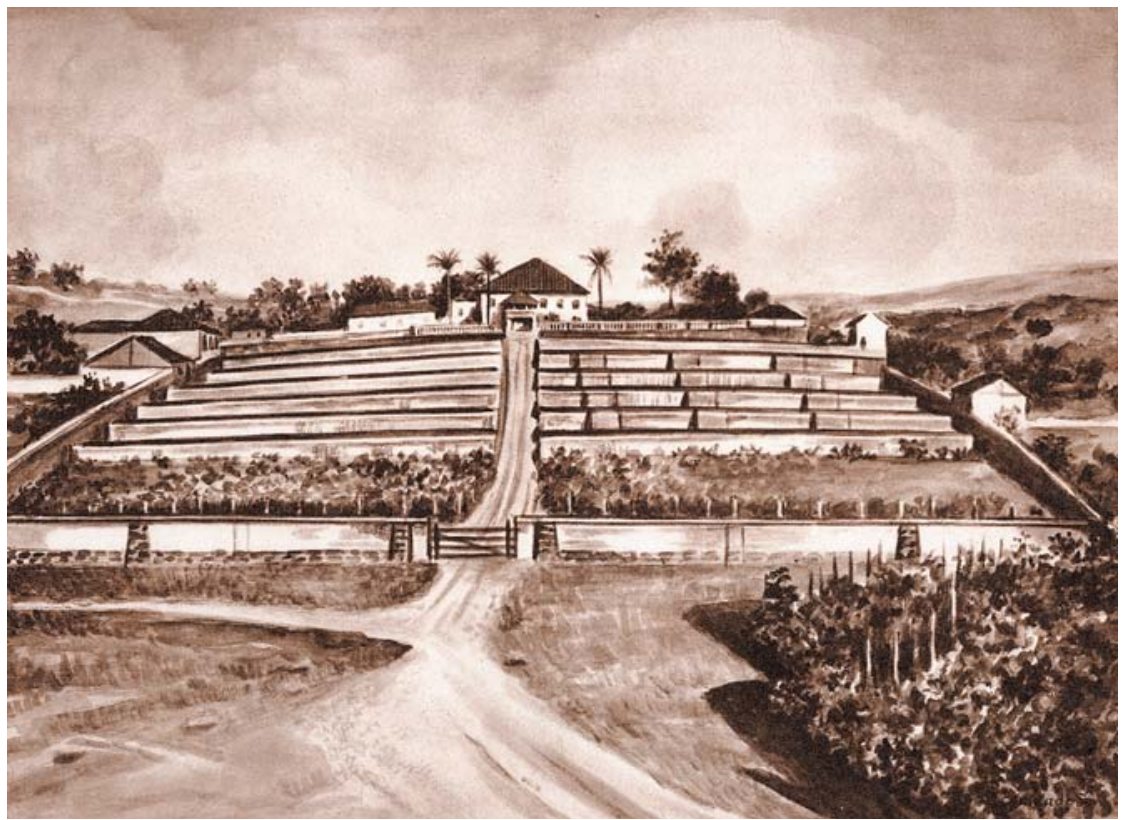

Figura 9 - Fazenda Bonfim. Fazenda de café (segunda metade do século XIX) agenciada em quadra a partir da centralidade dos terreiros, dispostos em patamares e conectados por canaletas e tanques d'água. No seu entorno estão: residência-sede, tulhas e casa de máquinas. José de Castro Mendes, s.d., aquarela (MENDES, 1947). 

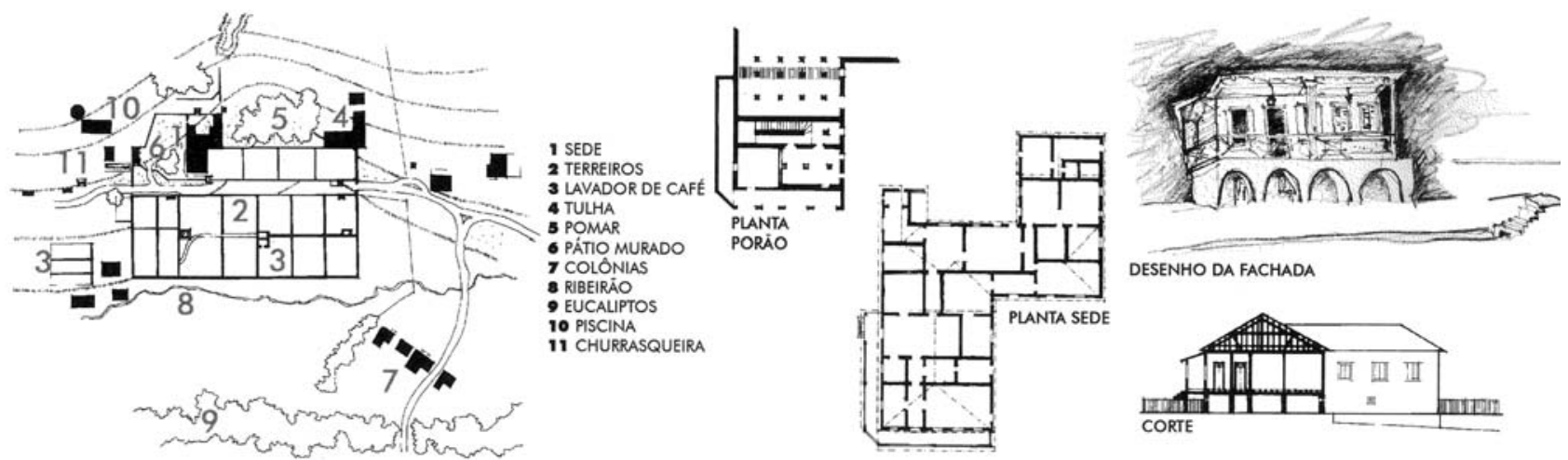

Figura 10 - Fazenda Iracema. Fazenda de café (segunda metade do século XIX), implantada a meia encosta, construída parcialmente sobre porão alto em alvenaria de tijolos. Planta irregular, alterada pelos acréscimos. Redesenho dos originais do arquivo do Condephaat.

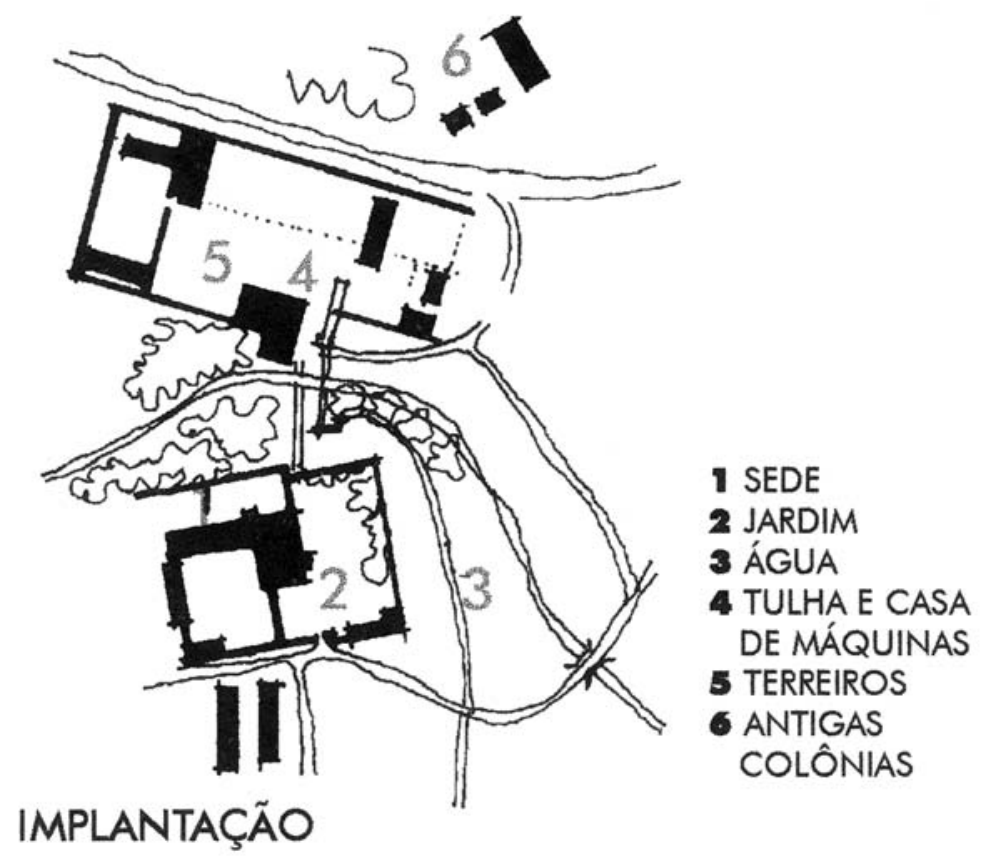

Figura 11 - Fazenda Cabras. Conjunto cafeeiro (segunda metade do século XIX) distribuído em três secções: sede e seus anexos, setor de trabalho, e antiga colônia. As primeiras delimitadas por muros, com destaque para o belo espaço do terreiro cercado por muros de taipa de pilão. Redesenho dos originais do arquivo do Condephaat. 

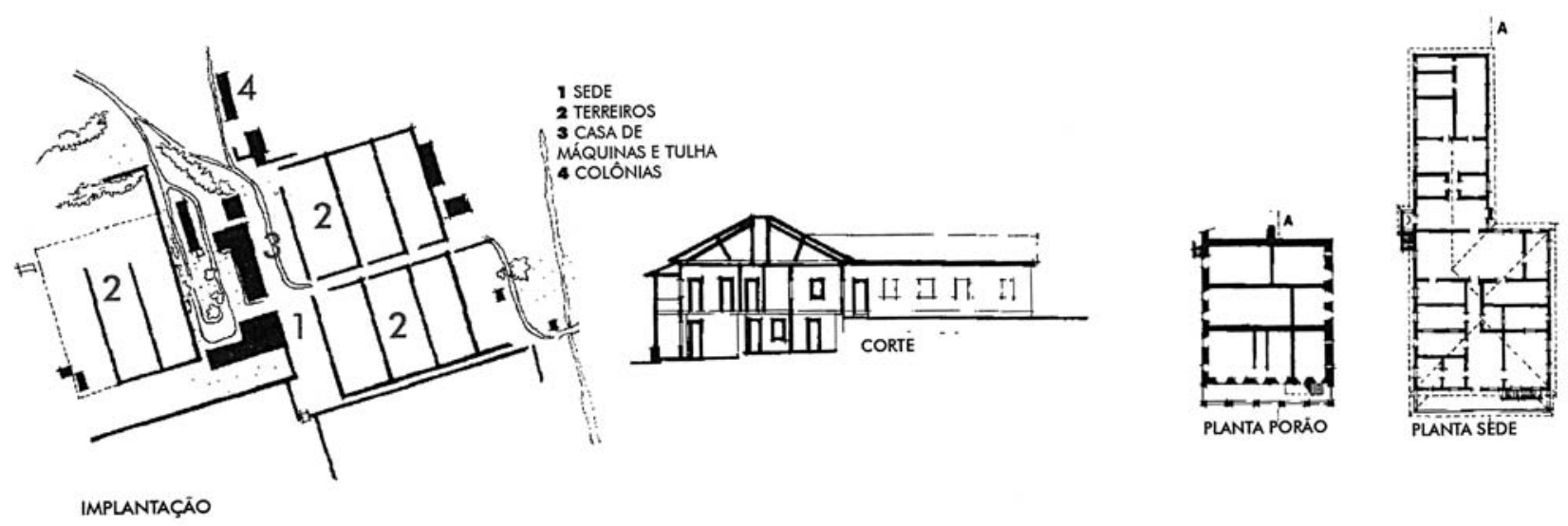

Figura 12 - Fazenda Sete Quedas (Jaguari). Fazenda de café, (meados do século XIX), que conserva casa-sede, casa de máquinas, tulha, colônias, terreiros de café divididos em dois segmentos e muros. Casa assobradada, implantada a meia encosta com planta em L. Redesenho dos originais do arquivo do Condephaat.

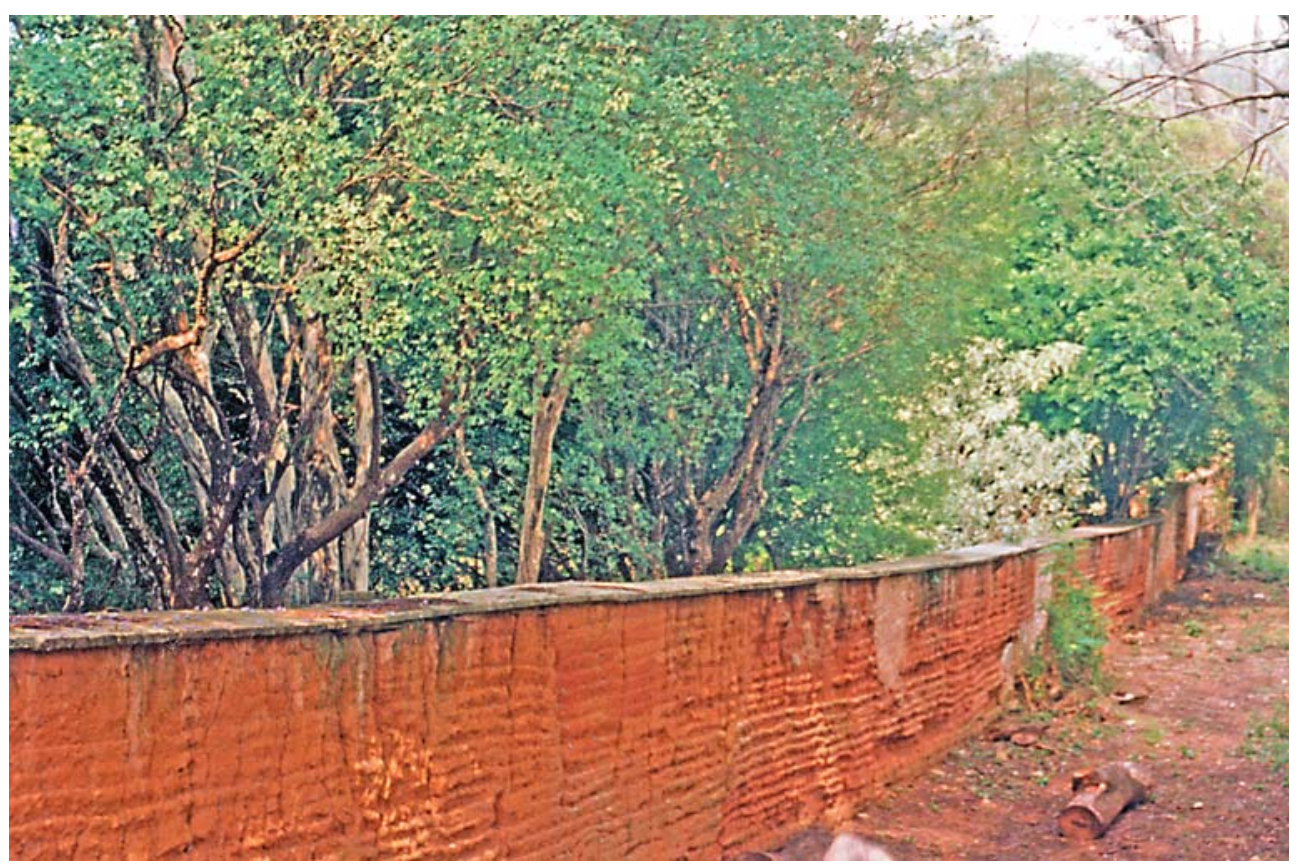

Figura 13 - Fazenda Sete Quedas (Jaguari). Restos do muro de taipa de pilão que cercava o espaço da sede. O telhadinho de telhas de barro desapareceu. Fotografia da equipe. 
estabelecer o controle e a vigilância sobre os escravos e a produção de café (Figura 13). Graças à geometria do seu traçado, eles acabaram reforçando a noção geral de organização em quadra, mesmo nos agenciamentos dispersos. Sua presença foi registrada em quase todas as fazendas, como ilustram os desenhos de implantação magistralmente executados pelo arquiteto Antônio Luiz de Andrade, as aquarelas de José de Castro Mendes e o inventário processado ${ }^{21}$.

Terreiros

"novo personagem", no dizer de Luis Saia, ocupa uma área privilegiada no contexto da sede da fazenda. Por estarem ligados às duas fases do beneficiamento do café - a lavagem e a secagem -, sua localização e implantação sempre dependeram da água e de uma boa insolação.

Grosso modo, foram arrolados dois tipos de terreiros: em superfície plana, como nas fazendas Capoeira Grande, Braga, São Pedro (Figuras 14 e 15), Iracema (Figura 16); ou dispostos em sucessivos patamares construídos com muros de contenção, como nas fazendas São Vicente, São Quirino, Bonfim, Sertão, Santana da Lapa, Jambeiro etc. Geralmente os muros de arrimo foram erguidos em alvenarias - de pedra e cal, e de tijolos. A Fazenda Quilombo conserva ruínas do antigo muro em pedra aparelhada de fatura esmerada.

No início da produção cafeeira, as grandes superfícies de terreiros eram de chão batido. Mas a necessidade de obter grãos de melhor qualidade, aliada ao desejo de diminuir os prejuízos na comercialização, fez com que, já por volta de meados do século XIX, os terreiros começassem a ser revestidos de tijolos. $\bigcirc$ emprego e a difusão desse novo procedimento foi possível graças à
21.Ver Andrade (1973).A referência básica para nosso estudo foi o material gráfico (plantas, cortes, implantação etc.) produzido pelo arquiteto durante o "levantamento preliminar" das fazendas na região campineira. Foram redesenhados por Débora Sanches e citados no texto como Fontes: redesenho dos originais do arquivo do Condephaat.
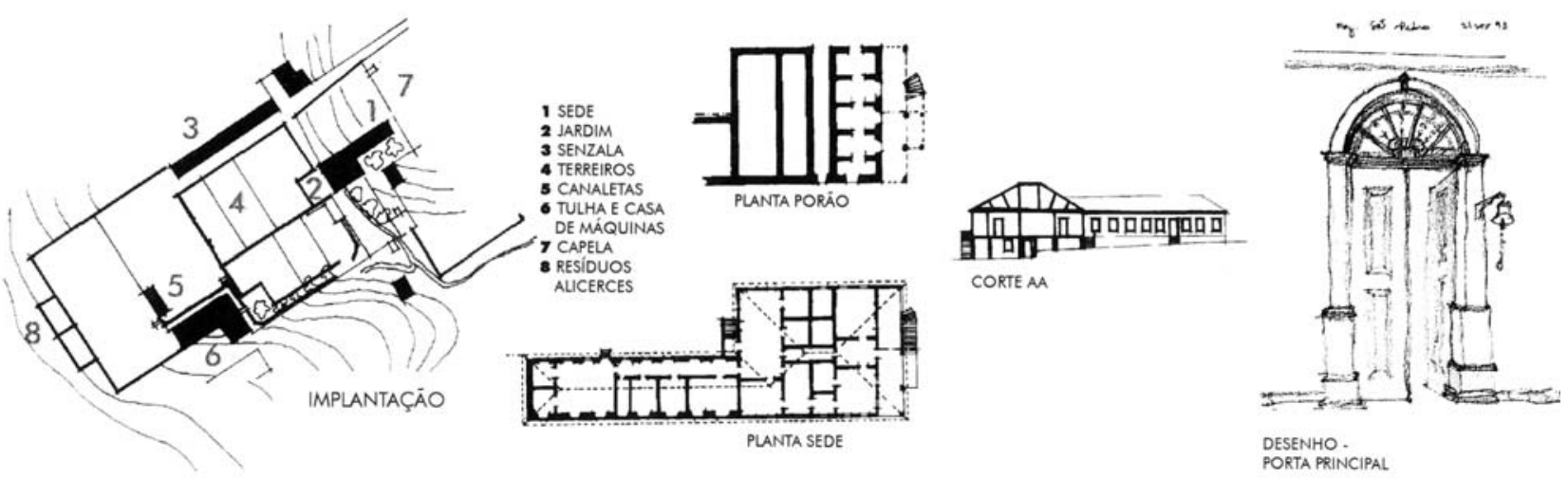

Figura 14 - Fazenda São Pedro. Fazenda de café (segunda metade do século XIX), cuja residência localiza-se diante dos terreiros dispostos em patamares e interligados por um sistema hidráulico de canaletes e tanques. À sua borda, em cota inferior, localizam-se a tulha e a casa de máquinas; à esquerda, a senzala. Todas as construções são de técnica mista em taipas. Redesenho dos originais do arquivo do Condephaat. 


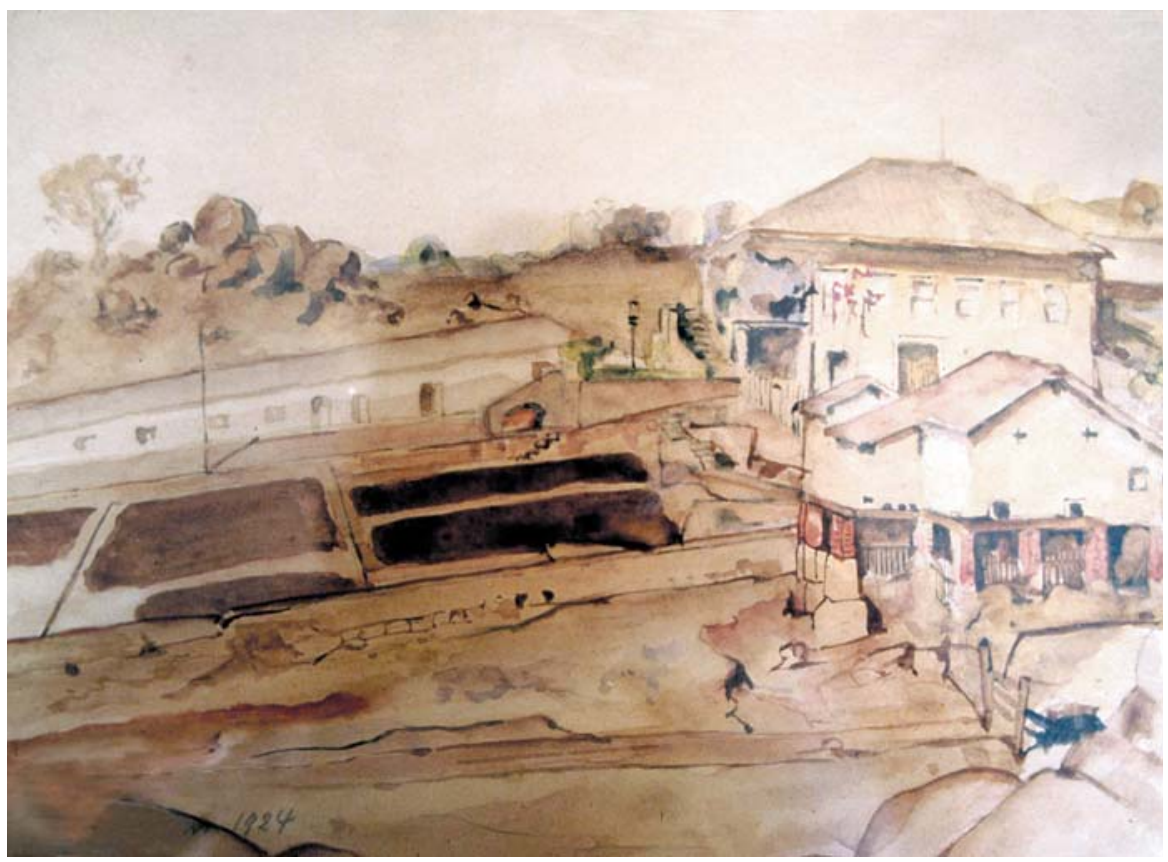

Figura 15 - Fazenda São Pedro. Desenho de 1924, assinado por Mario Bantilly (sic), conservado na fazenda, mostra uma edificação sobre pilares (destruída), o terreiro, a residência e a antiga senzala. Fotografia da equipe.

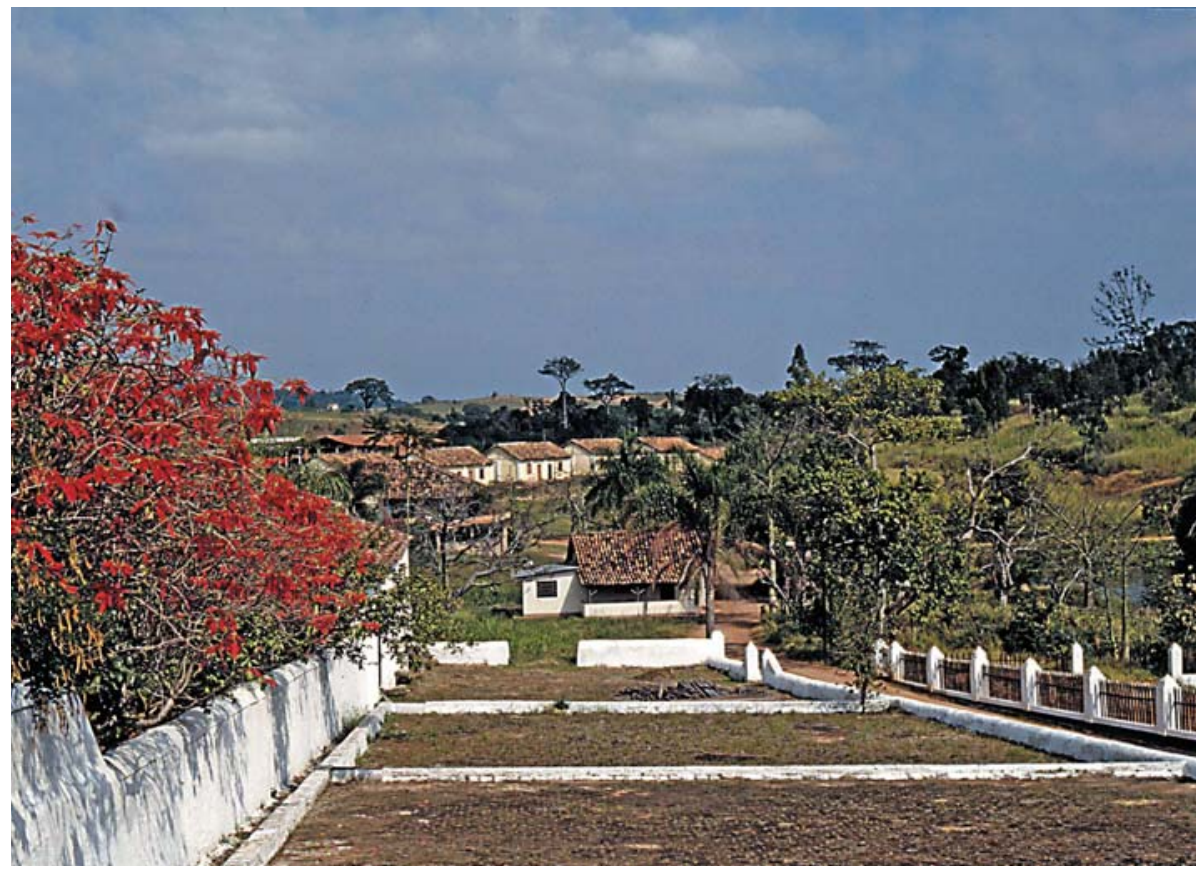

Figura 16 - Fazenda Iracema. Os terreiros localizam-se em frente e ao lado da residência, interligados entre si e aos tanques de lavagem de café por uma rede de canaletas. No plano recuado foram construídas as colônias. Fotografia da equipe. 
presença de pequenas olarias manuais, instaladas nas fazendas ou nos arredores de Campinas. No Almanaque da Província de São Paulo, de 1873, encontramos a relação de doze olarias em funcionamento só na cidade, além da célebre olaria mecanizada a vapor pertencente ao campineiro Carlos Sampaio Peixoto 22. Registramos a presença de olaria nas fazendas São Vicente, Sete Quedas do Jaguari (bairro de Carlos Gomes), Jambeiro, Iracema, Rio das Pedras e Sertão; e, nos inventários, "um vapor e serra [...] e pertences, existentes no lugar denominado Olaria" (Fazenda Morro Alto, 1873), assim como milheiros de tijolos foram arrolados entre os bens do barão de ltatiba, em 1882-188523.

Para atender às tarefas ligadas à lavagem do café, foram construídos, junto aos terreiros de secagem, lavadores e tanques interligados, alimentados com água e servidos por um sistema de canaletas que conduzia e distribuía o café por gravidade. Em algumas fazendas, o sistema foi usado com sofisticação, revelando um apurado conhecimento das formas de conduzir e controlar o fluxo das águas, ligando tanques, comportas, canais, aquedutos etc. Os exemplos mais interessantes foram arrolados nas fazendas Bonfim, São Vicente, São Quirino, Iracema, Braga etc. Desativados, muitos terreiros acabaram se transformando em jardins, como nas fazendas São Martinho (Figura 17), Mato Dentro (Jaguari), Pau d'Alho, Sertão etc., em pastos (Três Pedras) ou abandonados à própria sorte.

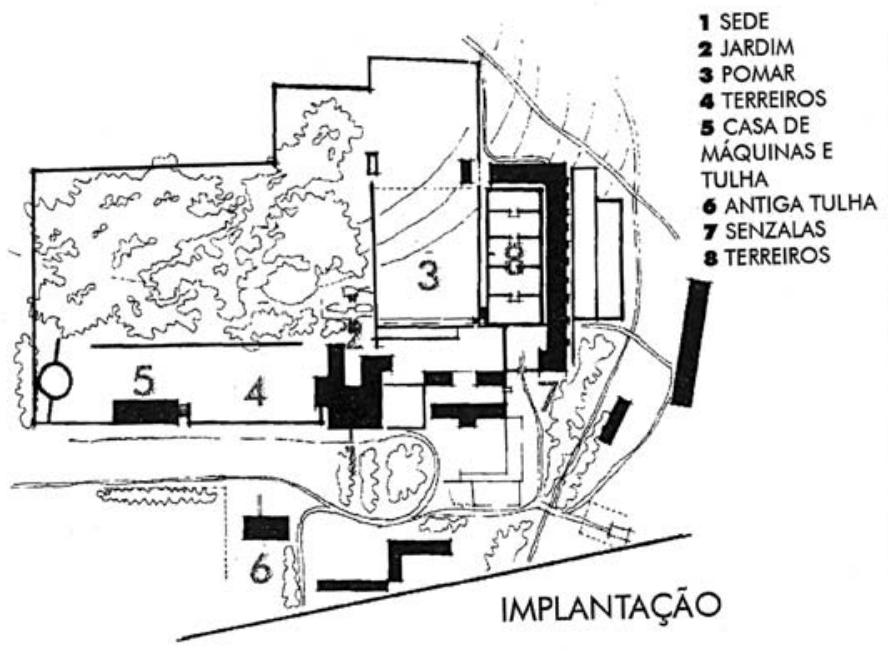

22. Lemos (1985, p. 4142) informa que essa grande olaria, inaugurada em 1876,ocupava, quatro anos mais tarde, uma área de 27.500 palmos quadrados, fazia por hora 1.500 tijolos, queimava 70 mil unidades por vez, chegando "à marca de um milhão de tijolos de diversas qualidades: sólidos para construção, tubulares de três espécies, ladrilhos, ditos para poços, enfim tubos para encanamentos".

23. Centro de Memória da Unicamp - TJC, cx. 211, pasta 4359; TJC, cx. 265, pasta 5224, Campinas.

Figura 17 - Fazenda São Martinho. Importante exemplar (primeira metade do século XIX) erguido no período do açúcar e modificado na época do café. Sede assobradada, implantada à meia encosta. A planta original em L foi ampliada em mais uma ala, à direita. Levantada sobre embasamento de taipa de pilão e paredes de taipa de mão. Conserva: tulhas, casa de máquinas e um segmento da senzala à direita. Fechamento do espaço com muros de taipa de pilão. Redesenho dos originais do arquivo do Condephaat. 
24. As memórias de um grão de café", escritas para O Vassourense. Ver Stein (1961, p. 44)

25. No Vale do Paraíba, esse dispositivo foi conhecido como riba: o método consistia em colocar o café a ser despolpado dentro de um cocho circular, onde era "esmagado" por uma roda pesada de madeira, que girava em círculos dentro do sulco, podendo ser movida por animais ou água.

26. Centro de Memória da Unicamp - TJC, cx. 76, pasta 1859 , Campinas

27. Sobre a primeira in dustrialização de Campinas, ver Camillo (1998).
Casas de máquinas e tulhas

[...] Tio Tomás me colheu. $\bigcirc$ capataz me viu com indignação cair fora do balaio, e considerando inepto ao velho escravo, açoitou-o e deu-the dois pontapés no traseiro. Chovia. Depois o sol me secou. Durante dois dias, um rolo estúpido me amassou como se quisesse quebrar-me a casca cada vez que me passava por cima. Finalmente, achando que eu estava suficientemente seco, passaram-me pela peneira. Daí me levaram para o monjolo. Fui arremessado ao ventilador donde saí pronto para ser ensacado [...] Da fazenda para o intermediário na estação, e dali para o Rio $[\ldots]^{24}$.

No que diz respeito ao setor produtivo, a casa de máquinas de beneficiar café foi o edifício mais importante e imponente do conjunto. Sua evolução acompanha os aperfeiçoamentos, os progressos tecnológicos efetuados na área da força motriz, com a substituição dos métodos arcaicos pelas novas técnicas: força animal, hidráulica, a vapor, a diesel, elétrica; e, na área dos implementos agrícolas, dos maquinários empregados nas múltiplas operações de beneficiamento dos grãos: secar, despolpar (descascar), abanar (ventilar), separar (escolher) e classificar.

De todas essas tarefas, vale a pena destacar a evolução tecnológica processada na atividade de despolpamento do grão, executada de diferentes maneiras. Nos estabelecimentos mais antigos, o café era socado em monjolos e em baterias de pilões, ou descascado por atrito, por meio de um mecanismo chamado, na região, de carretão ${ }^{25}$. No inventário de Francisco Egydio Souza Aranha, referente ao sítio do Mato Dentro (1861), esses mecanismos comparecem "com casas de moradas, senzalas, máquinas de pilões, moinho e ventilador tocados por água, máquina de carretão, duas tuias de guardar café, paiol [...], enfermaria, sala de escolha de café [...], tudo coberto por telhas, terreiro murado de enxugar café, tanque" 26 . Vale lembrar que o sistema de monjolo, pilões e carretão tinha suas desvantagens: era lento e danificava os grãos, produzindo uma grande quantidade de grãos quebrados, que acabava interferindo na qualidade final do produto.

A partir de meados do século XIX, inicia-se a substituição gradativa dos equipamentos tradicionais pelas novas e modernas máquinas de beneficiar café, que executavam com maior eficiência e rapidez todas as etapas do processo. $\bigcirc$ fato de Campinas concentrar um grande número de casas importadoras, de oficinas de reparo e montagens de máquinas, e sobretudo de fábricas de implementos agrícolas ${ }^{27}$, favoreceu enormemente a modernização, a eficiência e o barateamento da produção cafeeira. Para alojar essas máquinas, geralmente de grande porte, foi necessário ampliar a escala das construções, que passaram a ter pé-direito duplo e diferentes níveis, criando sobrados integrais ou parciais. Os melhores exemplos conservados estão nas fazendas São Martinho (Figura 18), São Pedro, Sertão, Atalaia, Cachoeira Grande, Monte d'Este, Recreio etc. 


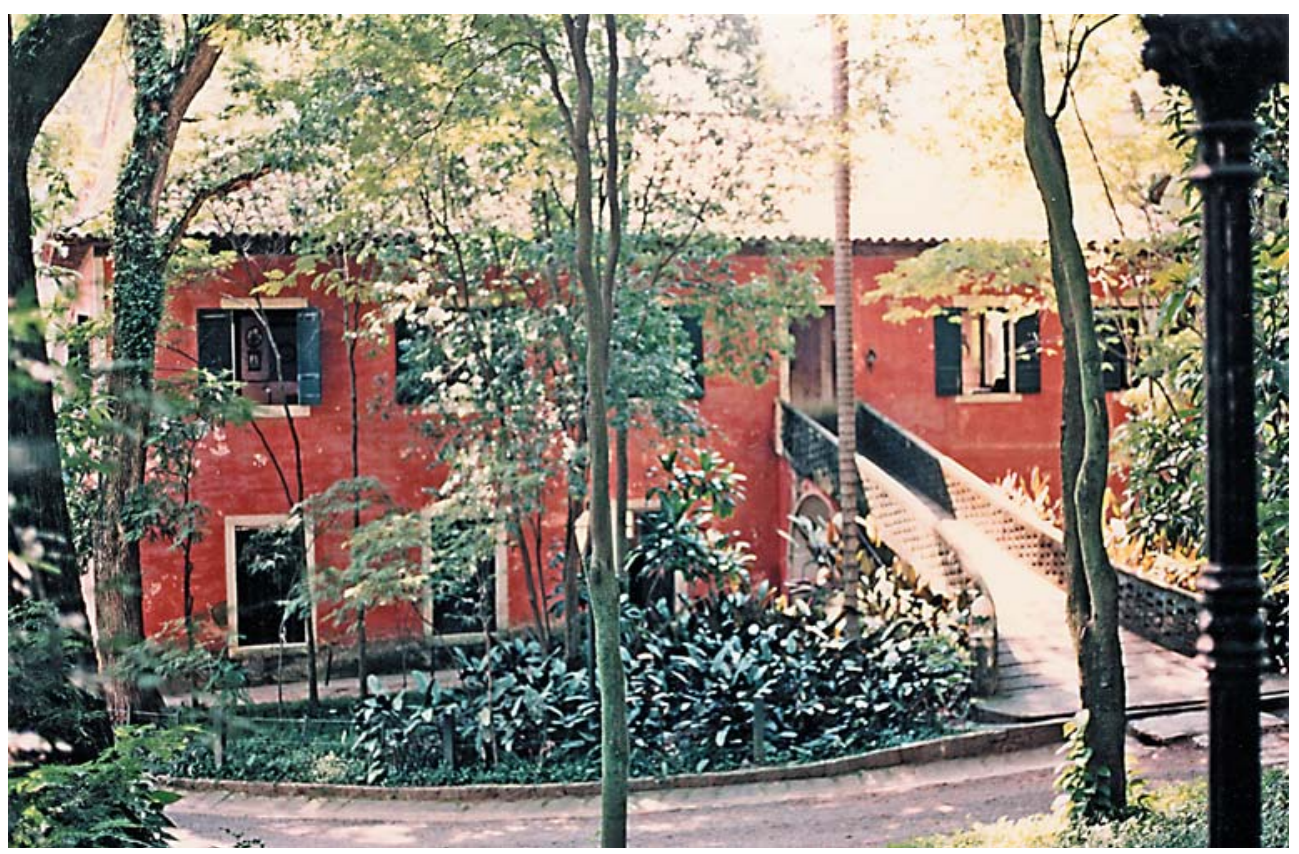

Figura 18 - Fazenda São Martinho. Tulha antiga. Sobrado construído em taipa de pilão, no pavimento térreo e taipa de mão no piso superior. Fotografia da equipe.

Como ao beneficiamento sucede o armazenamento, foi comum a casa de máquinas conjugar-se às tulhas. Concebidas como construções de generosas volumetrias, as tulhas apresentam-se assobradadas ou sobre porão, criando boas condições de isolamento dos grãos da umidade ao contato com o chão. Esse tipo de tulha foi documentado nas fazendas São Martinho, São Pedro (Figura 19), Recreio e nas duas Sete Quedas (Figura 20).

No que concerne à implantação e ao agenciamento da casa de máquinas e tulhas, foram registradas várias soluções. Algumas construções achamse situadas em uma cota inferior ao terreiro, facilitando o transporte do café deste para máquinas e tulhas; essa disposição aparece nas fazendas São Pedro, Atalaia, Sertão, Espírito Santo, São Martinho etc. Muitas vezes, o transporte era realizado por vagonetes, carrinhos que rodavam sobre trilhos, levando o café até a parte superior das tulhas, onde ficava armazenado até ser levado para a casa das máquinas para beneficiamento. Esse sistema foi encontrado nas fazendas São Vicente (Figura 21 ), Rio das Pedras, Sete Quedas do Jaguari e Espírito Santo. Na Fazenda Capoeira Grande, a casa de máquinas, as tulhas e os terreiros estão no mesmo nível. Na Fazenda São Quirino foi encontrado o único exemplar de tulha para depósito de café em coco erguida junto aos terreiros, enquanto a tulha de armazenagem do café despolpado localizava-se em outro sítio, acoplada à casa de máquinas.

Do ponto de vista construtivo, essas edificações dão testemunhos da diversidade das técnicas em voga na região ao longo do século XIX. As mais antigas empregaram as taipas, usadas separadamente ou conjugadas, e os 


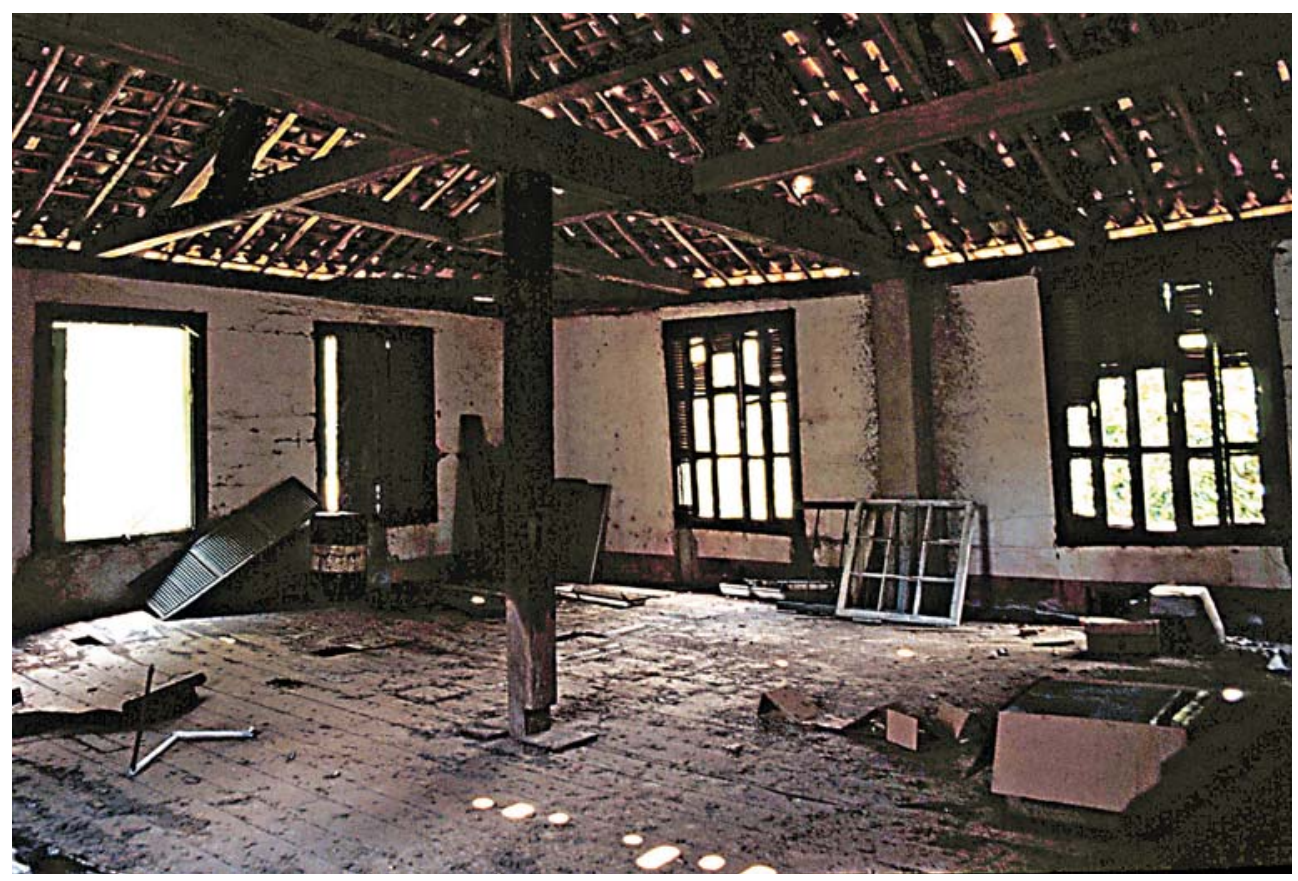

Figura 19 - Fazenda São Pedro. Interior da tulha e da casa de máquinas. Elas formam um só edifício de planta em L, sob telhado de 6 águas, embasamento de taipa de pilão e pavimento superior em taipa de mão. Implantado em cota inferior àquela dos terreiros. Fotografia da equipe.

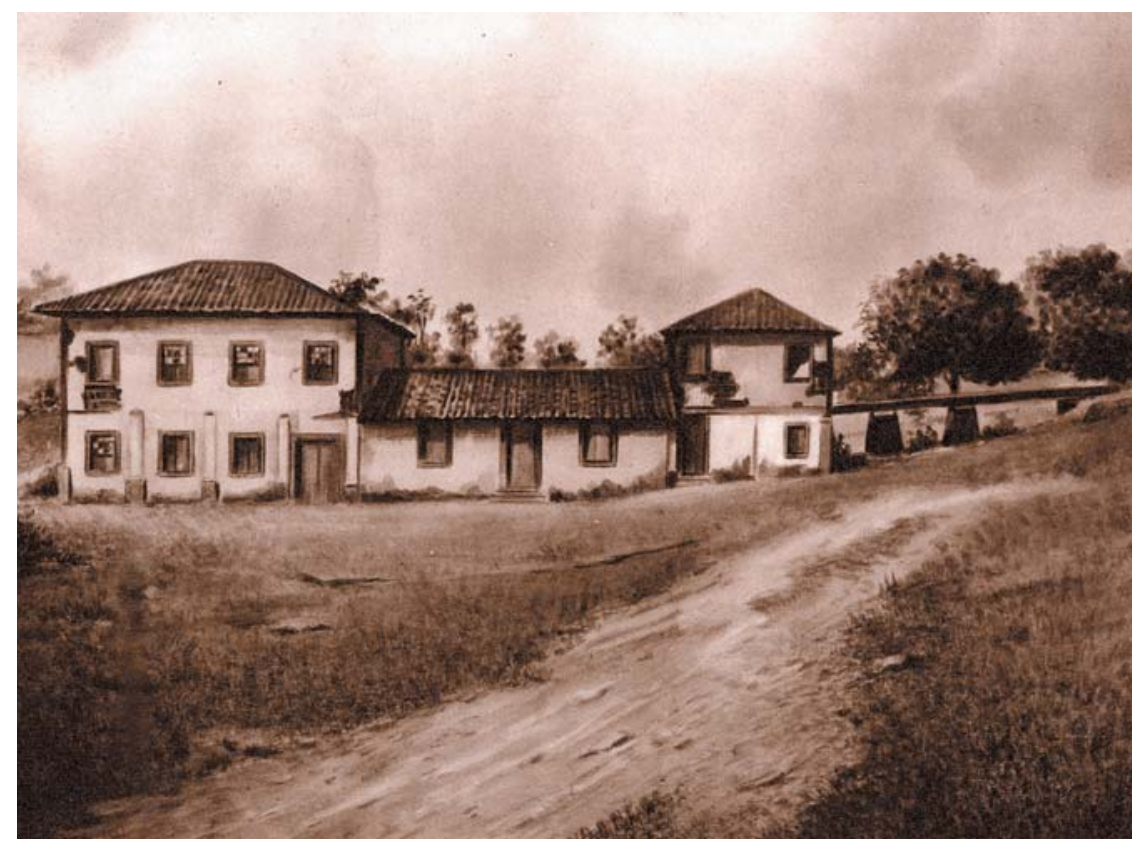

Figura 20 - Fazenda Sete Quedas. Propriedade do Visconde de Indaiatuba Isegunda metade do século XIXI, com tulha e casa de máquinas erguidas em taipa de mão. José de Castro Mendes, aquarela (MENDES, 1947). 


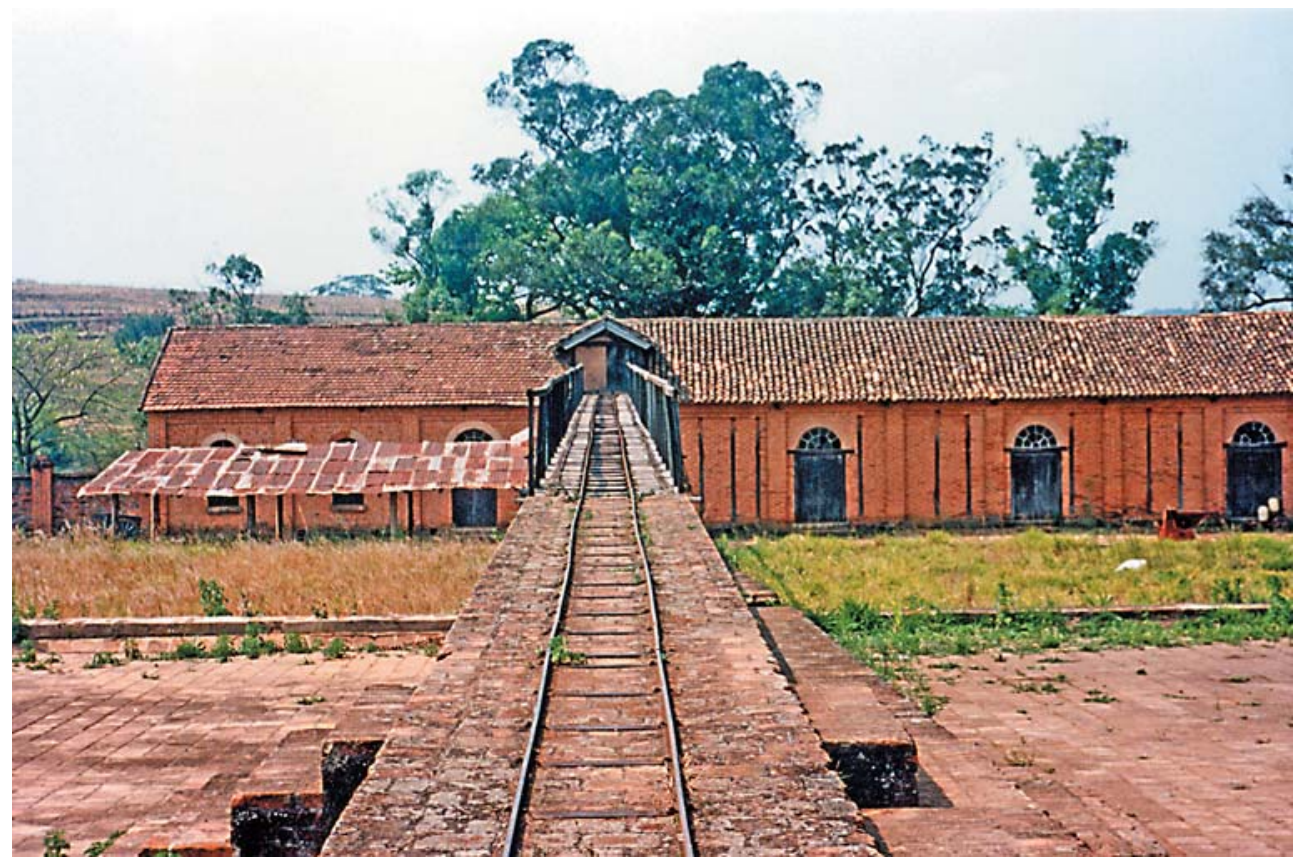

Figura 21 - Fazenda São Vicente. Erguida entre o final do século XIX e início do XX, possui sistema de trilhos e vagonetes usado no transporte dos grãos dos terreiros para a casa de máquinas. Os terreiros estão em cotas superiores e divididos em 6 quadros por canaletas. Fotografia da equipe.

exemplos mais interessantes estão nas fazendas São Martinho, São Pedro e Jambeiro, nas duas Sete Quedas, São Quirino, Bonfim etc. A partir do último quartel do século, a alvenaria de tijolos ganha a preferência como material construtivo, sendo empregada nas casas de máquinas e tulhas das fazendas Sertão, Mato Dentro e São Vicente (Figura 22). Nesta última, embora sejam projetados segundo exigências funcionais e pragmáticas, os edifícios revelam uma preocupação formal com o uso do tijolo aparente, que desenha as modulações das paredes e os perfis das envasaduras, à semelhança de uma construção urbana pós-ferrovia.

As residências dos proprietários

Por longas décadas do século XIX, a arquitetura cafeeira manteve-se vinculada à herança arquitetônica dos engenhos, revelada pela primazia das técnicas construtivas tradicionais e pela preferência por tipologias de casas assobradadas ou térreas, sempre organizadas em espaços internos segregados - salas sociais na frontaria, alcovas e quartos no centro, varanda latual sala de jantar) nos fundos, e área de serviços no prolongo ou puxado. A recorrência dessa herança mostra, sem dúvida, a permanência de formas sociais 


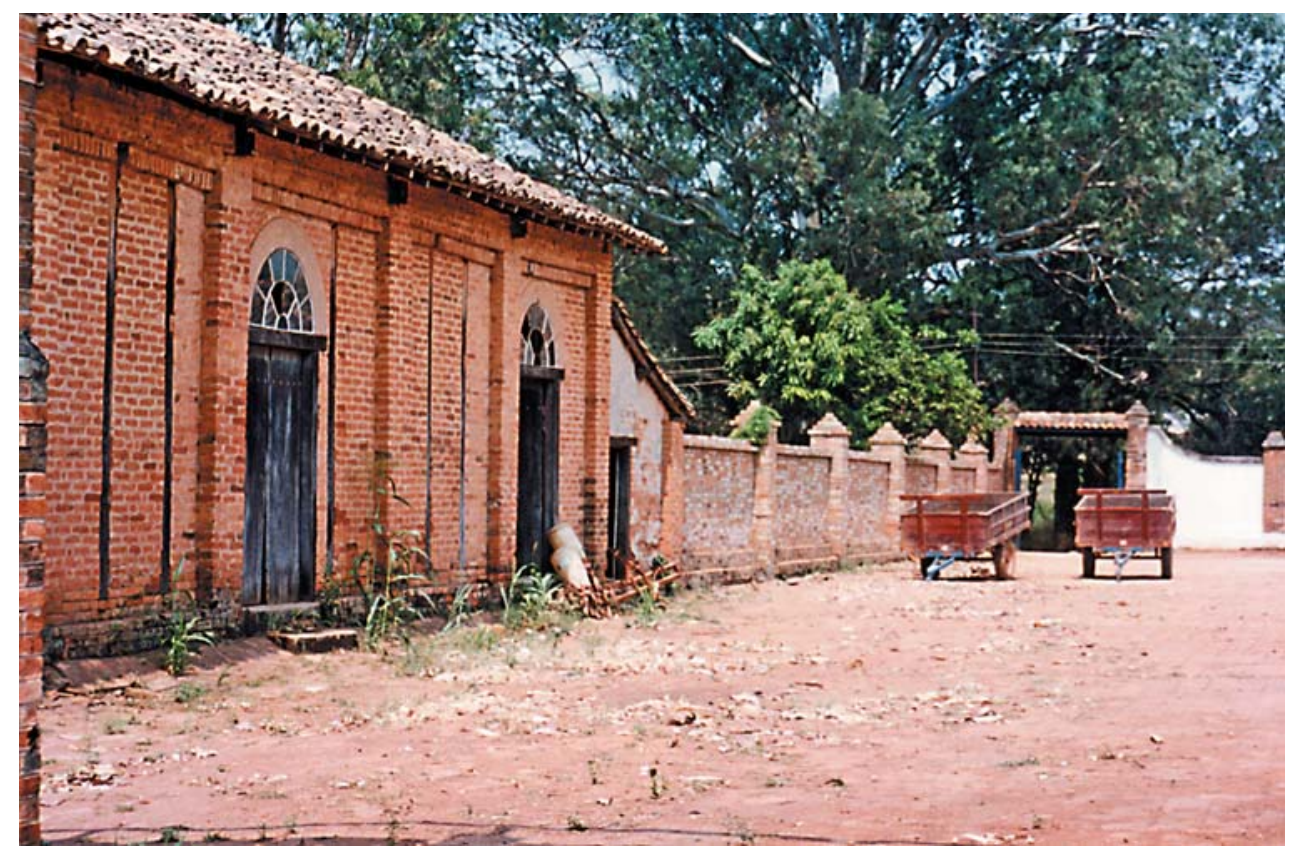

Figura 22 - Fazenda São Vicente. Casa de máquinas e tulha, erguidas entre o final do século XIX e início do XX. Edifício erguido em alvenarias de tijolos aparentes, sobre porão alto necessário à instalação de equipamento de benefício do café. Espaço interno único, com divisórias de madeira. Fotografia da equipe.

profundamente arraigadas na cultura local. Até a chegada da ferrovia, na década de 1870, o campineiro não ousou romper com o passado. Se o partido arquitetônico da residência permaneceu quase intacto até o último quartel dos oitocentos, a escala e a dimensão alteram-se visivelmente, seja no volume externo seja na ampliação dos espaços internos. Grande número de salas e salões foi anexado aos habituais quartos e alcovas.

Do ponto de vista da implantação, a arquitetura do café continuou a tradição, preferindo terrenos de meia encosta. Essa disposição topográfica exige estruturas de embasamento especiais, definidas quase sempre por muros de contenção e por grossas paredes de taipa de pilão. Sobre esse embasamento, repousa a estrutura da gaiola, formada por esteios, baldrames e frechais, da técnica do pau-a-pique. Assim foram erguidas as fazendas São Martinho, Santa Maria, Sete Quedas, Braga, Cabras, Fazendinha (ala esquerda, ampliada) etc. A Fazenda São Pedro (Figura 23) conjuga, no embasamento, a taipa de pilão com a pedra, enquanto na Três Pedras e na Bonfim (Figura 24) todo o embasamento foi executado em alvenaria de pedra. Na Fazenda Mato Dentro (Parque Ecológico), sobre as antigas paredes de taipa de pilão e pedra entaipada do período do açúcar, foram erguidas as paredes de vedação do pavimento superior em pau-a-pique, estruturado no sistema enxaimel, isto é, em vigas cruzadas e em alvenaria de tijolos, enquanto as divisões internas foram executadas em pau-a-pique. 


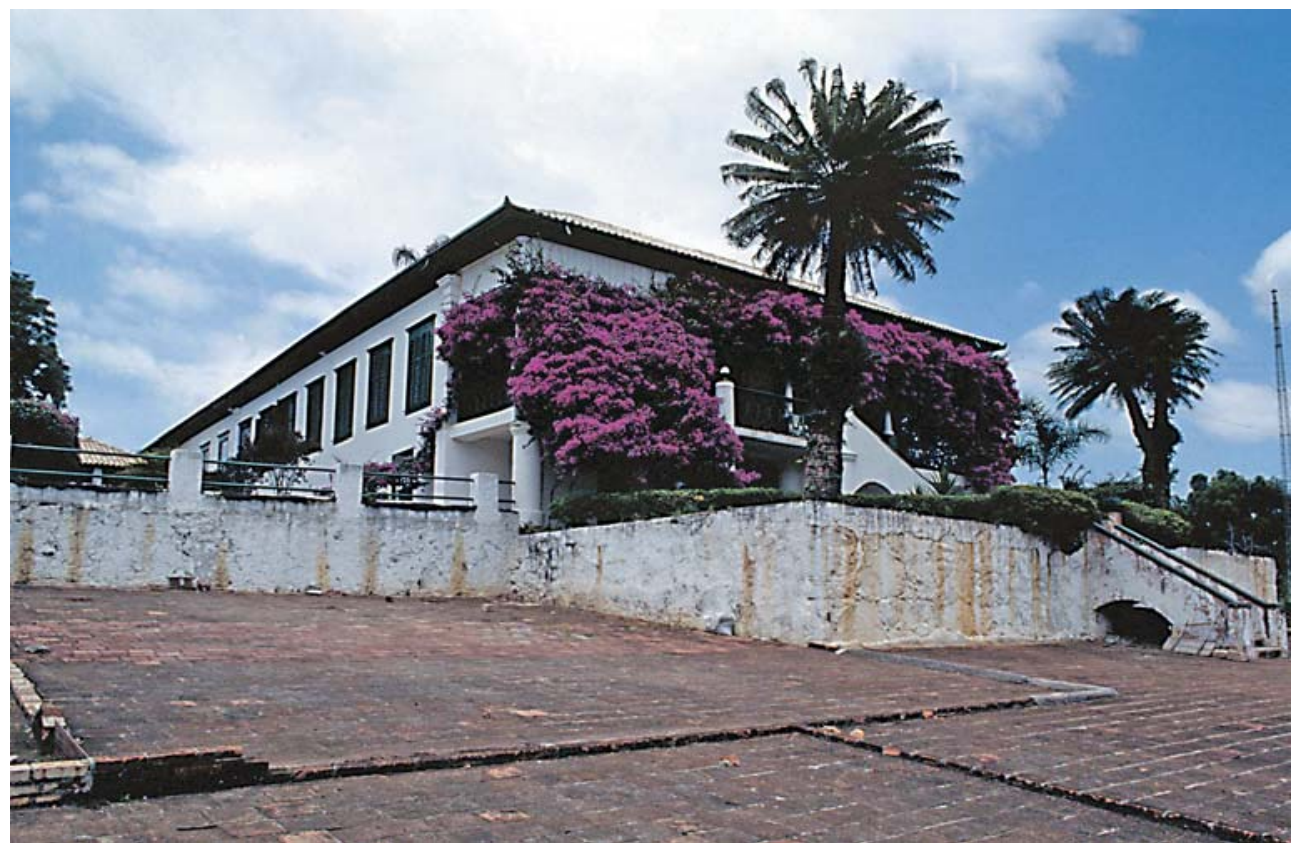

Figura 23 - Fazenda São Pedro. Residência assobradada, que ostenta na ferragem da porta principal a data 1872. Foi implantada em meia encosta, com planta em L. Construída em técnica mista: taipa de pilão (embasamento e paredes externas do pavimento térreo) e taipa de mão e tijolos (demais paredes). Fotografia da equipe.

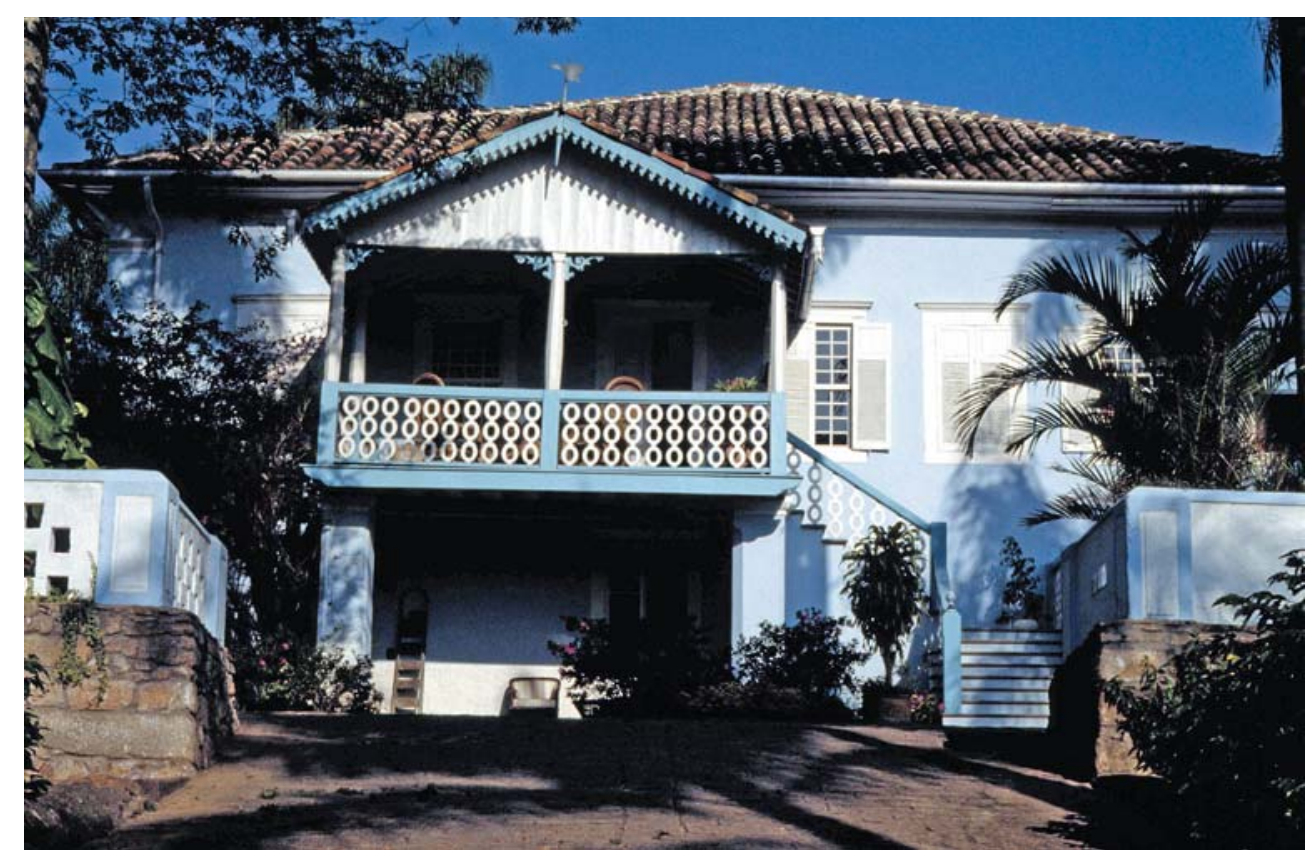

Figura 24 - Fazenda Bonfim. A residência assobradada acha-se a cavaleiro no terreno e implantada a meia encosta, definindo o esquema básico da planta em L. O terraço fronteiriço é acréscimo posterior. Fotografia da equipe. 
As casas térreas sobre barrotes conheceram certo enobrecimento e popularidade na época; por isolarem construtivamente os pisos da umidade do chão, essas moradias tornaram-se mais salubres e confortáveis, podendo ostentar vastos espaços soalhados. Curiosamente, é nesse grupo de casas que encontramos as intervenções mais radicais, marcadas pela substituição dos materiais e processos construtivos originais, como nas fazendas São Quirino, Atibaia, Capoeira Grande, Espírito Santo, Santa Mônica, Roseira, Tamburi etc. Resta lembrar, ainda, que, ao longo dos anos, foi comum e normal a substituição de antigas paredes (de vedação ou divisórias) por outras de tijolos; em certos casos, a perda das características originais foi irrecuperável, como na Fazenda Rio das Pedras.

Da última fase da arquitetura do café, identificada com o período republicano, foram arroladas duas residências térreas, nas fazendas São Vicente e Pau d'Alho, e uma assobradada, na Jambeiro. Construídas integralmente em alvenaria de tijolo, elas reproduzem, no contexto rural, certos aspectos da arquitetura urbana contemporânea. As duas casas térreas assentam-se em terrenos planos; no caso da São Vicente (Figura 25) foi criado um platô artificial, bastante regular, que permite ao porão manter estável a altura do pé-direito; já a Jambeiro preserva o esquema tradicional de implantação a meia encosta, definindo a fronteira assobradada e a parte posterior térrea. A tradição local tem atribuído os três edifícios ao escritório Ramos de Azevedo, entretanto as recentes pesquisas sobre o arquiteto não fazem menção a essas casas, como também não foram

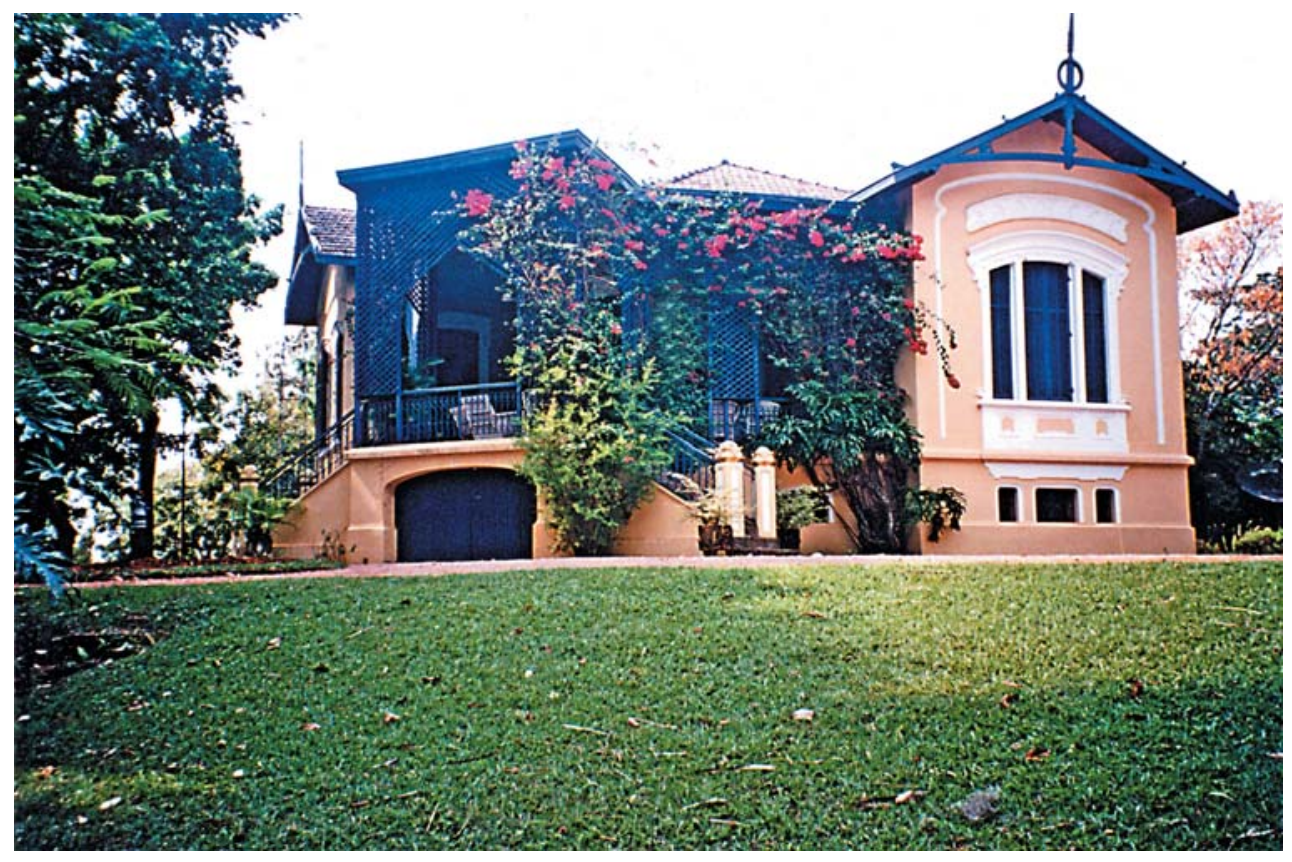

Figura 25 - Fazenda São Vicente. Residência térrea (início do século XX) com características arquitetônicas urbanas. Implantada sobre um platô artificial, foi construída em alvenaria de tijolos. Fotografia da equipe. 
localizadas nos arquivos conservados na Biblioteca da Faculdade de Arquitetura e Urbanismo da USP28. Mas, não há dúvida de que elas nasceram de um projeto arquitetônico e não da tradição local.

Com relação ao partido de planta adotado, à exceção da Fazenda Jambeiro, evidencia-se, nas duas residências térreas, uma profunda ruptura com os esquemas tradicionais; a antiga varanda desaparece, impondo-se agora a urbana sala de jantar distante da cozinha. Os materiais empregados, a linguagem formal e o requintado acabamento são expressões de hábitos citadinos transplantados para o campo.

Vejamos os aspectos internos dessas residências.

Grosso modo, a organização espacial apresenta muita analogia e, nesse aspecto, podemos dizer que "quem viu uma viu todas", parafraseando o engenheiro Vauthier, que escreveu sobre a casa brasileira dos oitocentos. A seqüência espacial - com salas na frontaria, alcovas e quartos no lanço intermediário, a varanda (sala de jantar) na parte posterior e cozinha e dependências de serviço no prolongo - é uma herança do engenho, que se generaliza e banaliza-se na segunda metade do século XIX. Essa tipologia foi capaz de responder ao programa de necessidades da sociedade cafeicultora. Variantes desse esquema colocam os quartos na frontaria principal. A novidade está na escala, uma vez que as residências se avantajaram; com a multiplicação dos cômodos, tornaram-se enormes. A varanda locupando toda a largura da casa) e a área de serviço (cozinha, dispensa, quartos da criadagem), ampliando consideravelmente seus espaços, testemunham o novo viver.

Independente de serem assobradadas ou térreas, as plantas mostram um esquema de circulação mais ou menos uniforme, uma vez que a morada propriamente dita desenvolvia-se em um único piso. Pequenas variações, como vestíbulos, corredores e número de salas, não chegaram a alterar sua configuração básica. Algumas plantas em L foram posteriormente ampliadas, dando lugar a novas alas e puxados, determinando o aparecimento de plantas em $U$, encontradas nas fazendas Atibaia, Capoeira Grande. São Martinho, Pau d'Alho, Roseira e Recreio.

Como bem lembrou Carlos Lemos (1978, p. 108, 11 1), o café foi o responsável por trazer os negros para o convívio da vida doméstica. "Somente agora no Império de D. Pedro II é que passou a tomar ciência da suntuosidade das casas enormes e de difícil manutenção, que somente poderiam funcionar à custa do escravo." Aqui o autor toma emprestadas as clássicas observações de Lúcio Costa (1975, p. 89-98):

A máquina brasileira de morar, ao tempo da colônia e do império, dependia dessa mistura de coisa, de bicho e de gente, que era o escravo. Se os casarões remanescentes do tempo antigo parecem inabitáveis devido ao desconforto, é porque o negro está ausente. Era ele que fazia a casa funcionar: havia negro para tudo - desde negrinhos sempre à mão para recados, até negra velha, babá. O negro era esgoto, era água corrente no quarto, quente e fria; era o interruptor de luz e o botão de campainha; o negro tapava goteira e subia vidraças pesadas $[\ldots]$.
28. Francisco de Paula Ramos de Azevedo (18511928) estudou na Bélgica (Gand), na escola filiada à École des Beaux-Arts francesa. Regressou a Campinas em 1879, onde atuou até 1886 , projetando-se no cenário local graças à conclusão da matriz de Nossa Senhora da Conceição. Foi funcionário-engenheiro das Companhias de Estrada de Ferro Mogiana e Paulista. Sua atuação em Campinas abrange tanto o campo do urbanismo como o da arquitetura. Sobre o arquiteto, ver Monteiro (2000) e Lemos (1993). 
E devia ser assim nessas residências campineiras...

Nas casas de dois níveis, o pavimento inferior sempre foi reservado para depósitos, senzala doméstica ou instalações acessórias. A julgar pelos exemplos inventariados da época do café, foi rara a utilização do porão como acesso principal da casa. Esse procedimento foi verificado nas duas fazendas Sete Quedas (Figura 26). Naquela localizada no distrito de Carlos Gomes, foi acrescentado um alpendre, já no início do século XX. Felizmente, encontramos no porão a antiga soleira de pedra da porta de entrada principal e, com os proprietários, uma foto da fachada, anterior à reforma de 1905, mostrando o acesso pelo porão. A falta de outros exemplares pode ser atribuída às freqüentes reformas das fachadas, tirando e pondo alpendres e mudando os acessos originais. No caso das sedes das fazendas Sertão e Iracema, houve o deslocamento do alpendre para a fachada lateral.

Sobre o alpendre, considerado elemento típico da arquitetura cafeeira, pairam muitas dúvidas, que vão desde o conhecimento de suas origens no universo luso-brasileiro até sua chegada à região de Campinas. $\bigcirc$ debate permanece em aberto, dividindo os historiadores. Para Lemos (1999, p. 221 ), o alpendre campineiro, de pouca profundidade, não seria tributário dos largos alpendres mineiros ou baianos; os campineiros "não passavam [...] de meros passadiços elevados instalados nas fachadas assobradadas". $\bigcirc$ fato de ser um elemento justaposto à fachada, portanto de fácil remoção ou alteração, dificulta

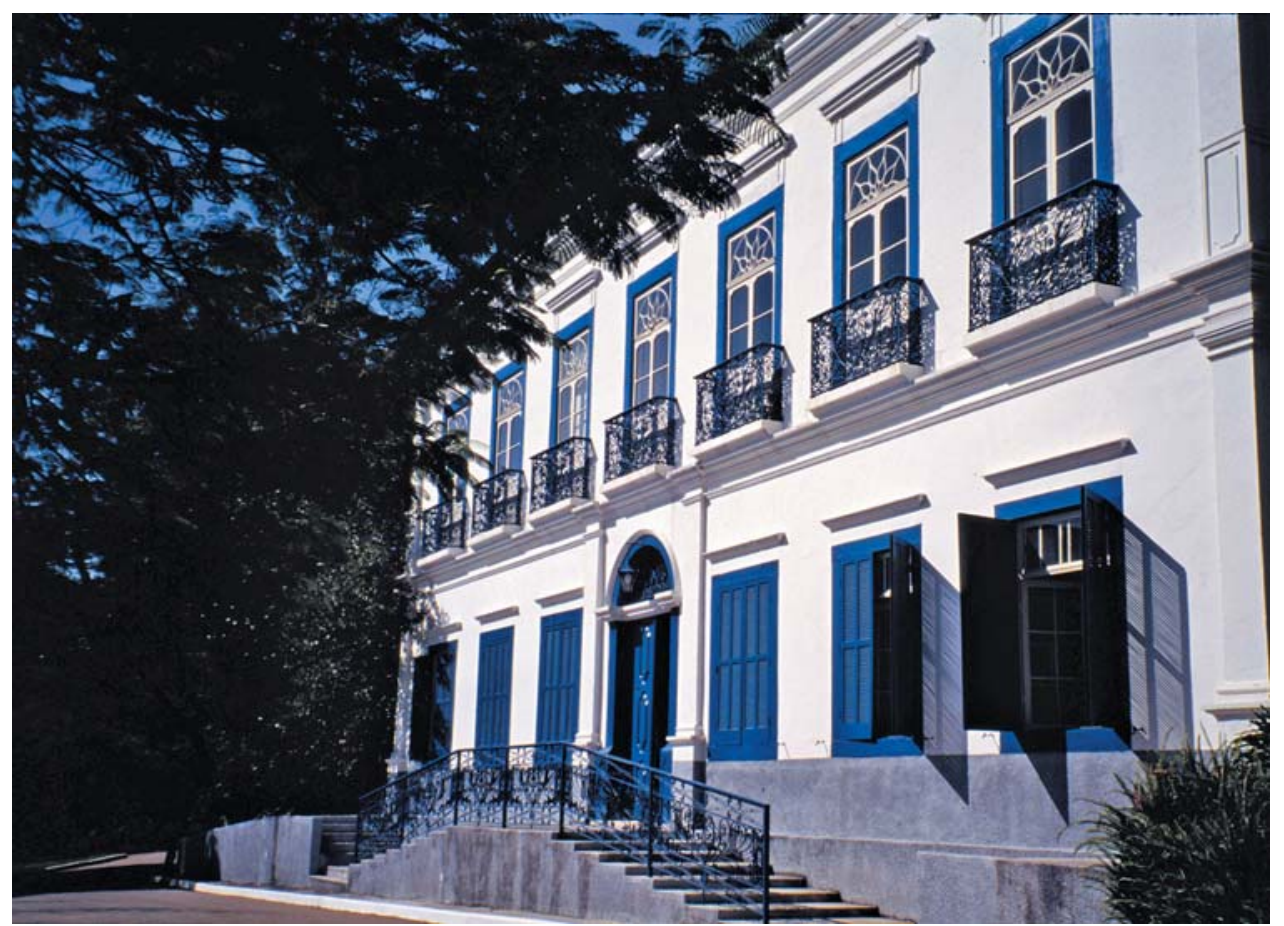

Figura 26 - Fazenda Sete Quedas. Residência do Visconde de Indaiatuba na segunda metade do século XIX. Sobrado implantado a meia encosta. Fachada tripartida, com o corpo central saliente, ostentando elementos neoclassicizantes. Fotografia da equipe. 
qualquer análise tipológica e evolutiva desse espaço. Grosso modo, no início eles foram executados integralmente em madeira: pilares, vigas, escadas de acesso, piso de tabuado corrido, guarda-corpo e lambrequins (Figura 27), como mostram as aquarelas de Castro Mendes ${ }^{29}$. Na virada do século, esse material seria substituído pelo ferro, quando entram em voga as grades e as colunetas de ferro fundido, como aparecem exemplarmente na Fazenda Sete Quedas (Figura 28).

Duas outras intervenções merecem destaque, pela apropriação extravagante que fizeram do ecletismo em voga. Na Fazenda São Martinho, o antigo alpendre de madeira - que aparece na aquarela de Castro Mendes foi eliminado por ocasião da reforma da fachada executada pelo arquiteto

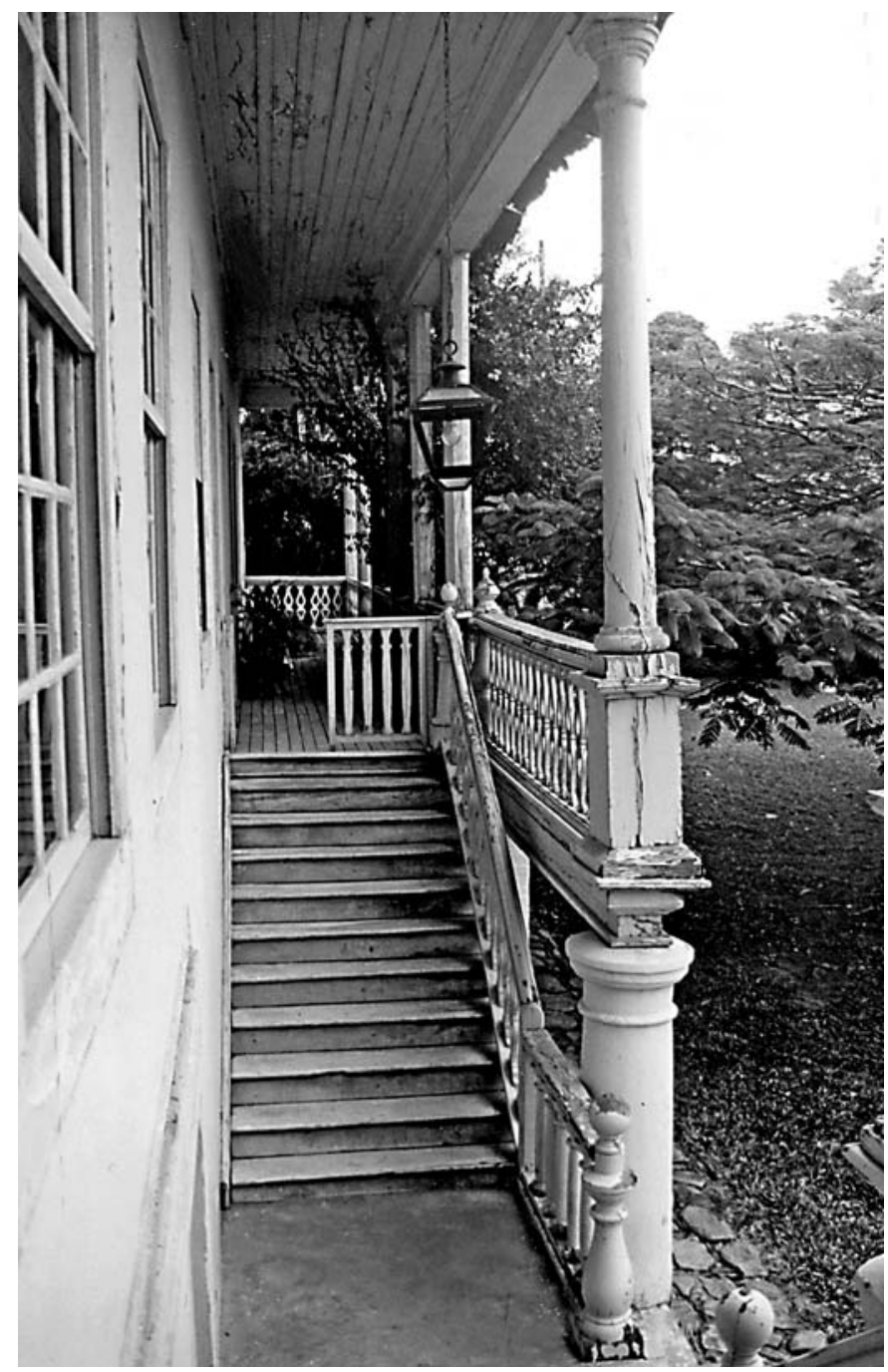

Figura 27 - Fazenda Fazendinha. Detalhe do alpendre frontal erguido em madeira sobre colunas e pilares de alvenaria. Fotografia da equipe. 


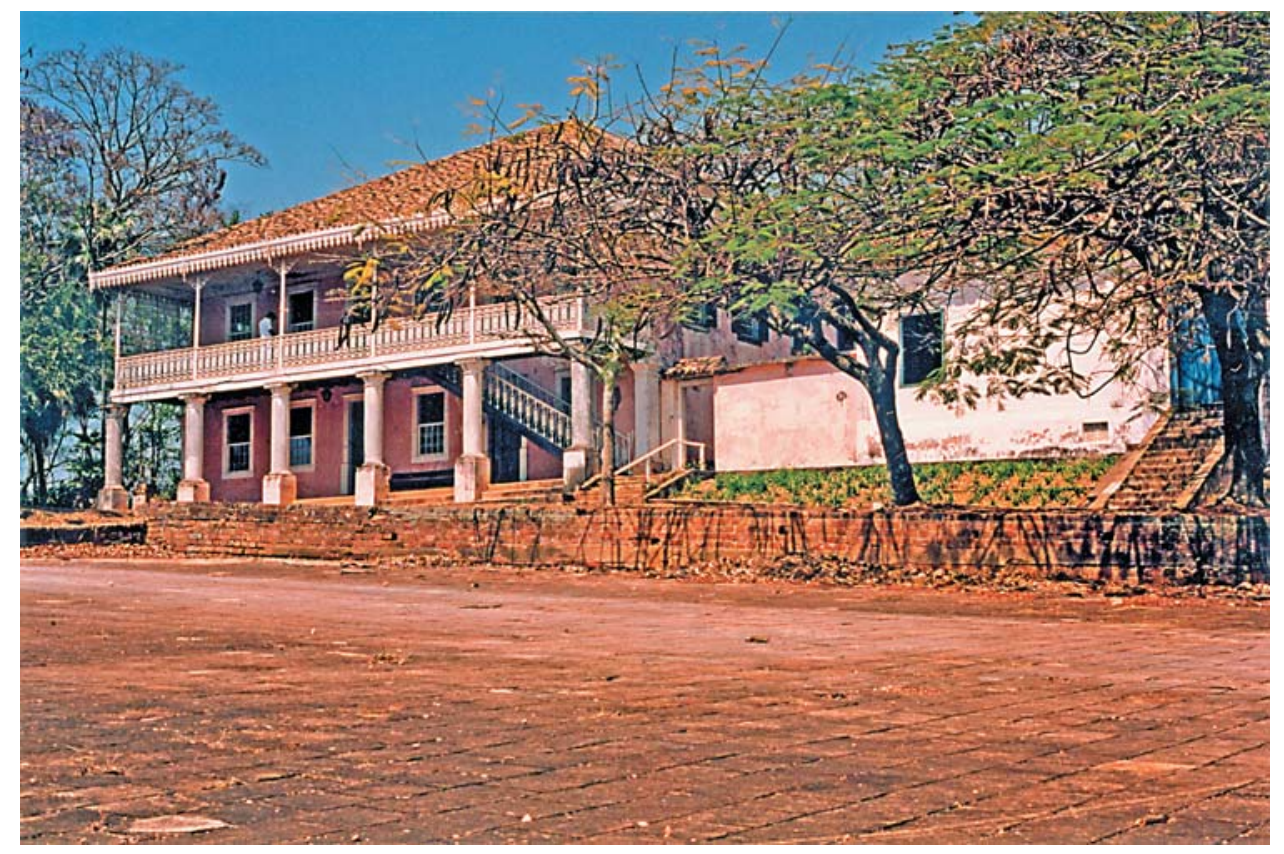

Figura 28 - Fazenda Sete Quedas. Residência da segunda metade do século XIX, assobradada, implantada a meia encosta, edificada em taipa de pilão e taipa de mão, organizada dentro de uma planta em L. Com a construção do alpendre em ferro, datada de 1905, alterou-se o acesso original. Fotografia da equipe.

Jacques Pilon, provavelmente no final dos anos 1940, quando foram incorporadas colunas colossais, à georgiana. Na Fazenda Recreio, o tratamento monumental dado à escada de acesso e ao alpendre transformou a residência em uma espécie de cenografia hollywoodiana.

Outro elemento modernizador das residências foi o vidro. A solução de vidraça de guilhotina para as janelas foi fácil, pois bastava enxertá-las nas estruturas dos batentes construídos. Nesse caso, as vidraças aparecem externamente. $\bigcirc$ vidro também popularizou o emprego das bandeiras como fonte de luz, melhorando a salubridade dos cômodos internos.

Do ponto de vista formal, até o final do século XIX as residências conservaram seu aspecto arquitetônico prismático e severo, determinado pela estabilidade da taipa e pelo retângulo dos telhados de quatro águas. Foi muito tímido o emprego de platibandas, frontões e corpos salientes na estruturação das fachadas, como mostram as sedes das fazendas São Vicente, Jambeiro e São Quirino. No que diz respeito à ornamentação interna, poucas pinturas murais chegaram até nós. Os exemplares arrolados estão nas fazendas Iracema, Mato Dentro, Recreio e São Vicente. Na sede da Fazenda Mato Dentro existem faixas decorativas com motivos florais e alguns murais representando animais e frutos. Na São Vicente, a decoração pictórica em faixa mostra motivos florais inspirados no art nouveau do início do século XX, variando a temática de cômodo para cômodo. A antiga varanda da residência da Fazenda Iracema conserva 
uma série de painéis parietais de inspiração acadêmica, representando naturezamorta e paisagem, e alguns retratam aspectos da própria fazenda. Segundo Pupo (1983), as pinturas murais da Fazenda Recreio foram executadas pelos pintores Hilarião da Cunha e José Pedro de Góis no ano de 1887, e representam naturezas-mortas de concepção acadêmica. Usou-se com parcimônia o estuque, reservado para algum detalhe de forro. $\bigcirc$ requinte dessas casas podia residir em algo fora da arquitetura propriamente: no modo de vida mais sofisticado, na numerosa criadagem, no mobiliário importado, nas festas... A leitura dos inventários pode jogar luzes sobre esses cenários, trazendo de volta o recheio dos ambientes. Assim, no inventário de Maria Luísa de Souza Aranha, viscondessa de Campinas, de 1879, os diversos móveis e objetos foram arrolados segundo seu ambiente:

Pela mobília da sala principal contendo um sofá, dois aparadores, meza de centro, com tampa de mármore, 22 cadeiras de assento de palhinha sendo quatro de braços, tudo em bom estado, dois marquezões com colxões, espelho grande, lavatório pequeno com tampo de mármore, criado-mudo, dois pares de jarros pequenos. Pela mobília da segunda sala constando de: uma marqueza, 14 cadeiras com assento de palhinha, sendo duas de braço, dois aparadores, uma meza de centro com tampo de mármore, dois marquezões com coxões, catre antigo com coxão, lavatório ordinário, lavatório com tampa de mármore, piano usado. Saleta da varanda: cama de armação, armário oliado, cômoda antiga em bom estado, lavatório com tampa de mármore, banheira de folha usada. Segunda saleta da varanda: cama do systema antigo e colxão, lavatório com tampa de mármore com suas pinturas, espelho antigo, meza redonda ordinária, cama de criança, cama forrada de couro, criado-mudo, guarda-comida velha. Varanda: dois espelhos antigos, meza antiga de jantar, dita tão bem estragada, duas ditas menores, ainda novas, sofá antigo, cama antiga com cabiceira, armário ordinário, onze cadeiras ordinárias, lampião para kirosene com três globos, relógio com caixa, guarda louça de copa, trem de cozinha, louça de serventia da caza comprehendendo apparelho de jantar, chá e christais, latas e mais objetos de dispensa ${ }^{30}$.

Senzalas

$\bigcirc$ aumento da escravatura na região espelha-se claramente nos inventários de Francisco Egydio Souza Aranha, 1861 (no Engenho Mato Dentro: 241 escravos; na Fazenda São Francisco: 56); Francisco Teixeira Vilella, 1873 (Fazenda Santa Maria: 361 escravos; Fazenda Morro Alto: 108 escravos); Maria Luísa de Souza Aranha, viscondessa de Campinas, 1879 (Fazenda Mato Dentro: 230 escravos); barão de Itatiba, 1882-1885 (Fazenda de Atibaia: 127 escravos; Fazenda das Cabras: 103 escravos); visconde de Indaiatuba, 1884 (Fazenda Sete Quedas: 196 escravos; Fazenda Salto Grande: 43 escravos) ${ }^{31}$. São dados estatísticos expressivos. Nessas listagens são registrados: nome, idade, certas características físicas (por exemplo, crioulo, preto, defeito físico) e, sobretudo, o valor da peça. Às vezes, eram indicados a procedência (por exemplo, de Benguella) e o ofício (ferreiro, telheiro, tropeiro etc.).

30. Centro de Memória da Unicamp - TJC, $1^{\text {a }}$ Ofício, ano 1879 , Campinas.

31. Centro de Memória da Unicamp - TJC, cx. 76, pasta 1859; TJC, cx. 211, pasta 4539; TJC, cx. 265 , pasta 5224;TJC, cx. 266, pasta 5225, Campinas. 
32. Sobre esses espaços consultar Stein (1961, p 210).
Das senzalas destinadas a abrigar essa numerosa escravaria, poucos vestígios chegaram até nós. Reduzidas, hoje, a restos arqueológicos, o estudo dessas habitações depende, em parte, de outras fontes, como os testemunhos escritos, os inventários e a restrita iconografia encontrada na região. Embora o trabalho escravo fosse a viga mestra da fazenda de café por muitas décadas, a entrada de mão-de-obra assalariada e a abolição da escravatura fizeram as senzalas perderem sua função e existência.

Pelos poucos exemplares arrolados durante a pesquisa, podemos afirmar que Campinas preservou o hábito de agrupar as senzalas em lanços sucessivos, com telhado corrido de duas águas, sobre uma plataforma ou implantadas diretamente no chão. Sob o aspecto do agenciamento, elas poderiam estar dispostas em uma só linha, como na Fazenda São Pedro, ou arranjadas em quadra, típica dos estabelecimentos de grande porte, que possuíam enormes contingentes de escravos. A concentração dos escravos em área relativamente pequena, dentro de um espaço quadrado, fechado, o curro, como era chamado, permitia maior controle e vigilância. Assim a filha do barão Geraldo de Rezende descreve a senzala da Fazenda Santa Genebra: "[...] lá por cima ficava o 'quadrado', com as senzalas, a dormida dos escravos, pequenos quartos em volta de um grande pateo, fechado por um portão, que se trancava, à noite, com enorme e impressionante chave, a fim de evitar facilidades aos fujões [...] aos 'caiamboras'" (MARTINS, 1939, p. 157).

Nas fazendas São Martinho, Quilombo, Três Pedras, Pau d'Alho (Figura 29) e Rio das Pedras, foram encontrados restos arqueológicos e testemunhos iconográficos de senzalas em quadra. Entre todas, a da Fazenda São Martinho é com certeza a mais importante (Figura 30). O que a singulariza é, sem dúvida, a implantação. Embora mutilada, mantém a visibilidade do quadrado, a escala original e a bela inclinação do telhado. Do quadrado da senzala da Fazenda Quilombo, hoje adaptado para moradia, restam apenas dois segmentos em forma de L, algumas fotos antigas que mostram o portão de entrada da senzala, aberto na própria taipa, e o depoimento do proprietário atual, confirmando que as portas originais da senzala abriam-se para dentro, isto é, para o pátio.

A tecnologia empregada nesses edifícios foi a tradicional taipa de pilão nas paredes externas, com possíveis divisórias em pau-a-pique. Portas e janelas garantiam uma mínima ventilação aos espaços de acanhado pé-direito. Não registramos nenhuma presença ou restos arqueológicos das cozinhas e enfermarias associadas às senzalas ${ }^{32}$.

\section{Colônias}

A presença da mão-de-obra estrangeira e assalariada nas fazendas trouxe um novo elemento à paisagem rural: a colônia, conjunto de moradias originalmente reservadas aos trabalhadores imigrantes. No inventário do visconde 


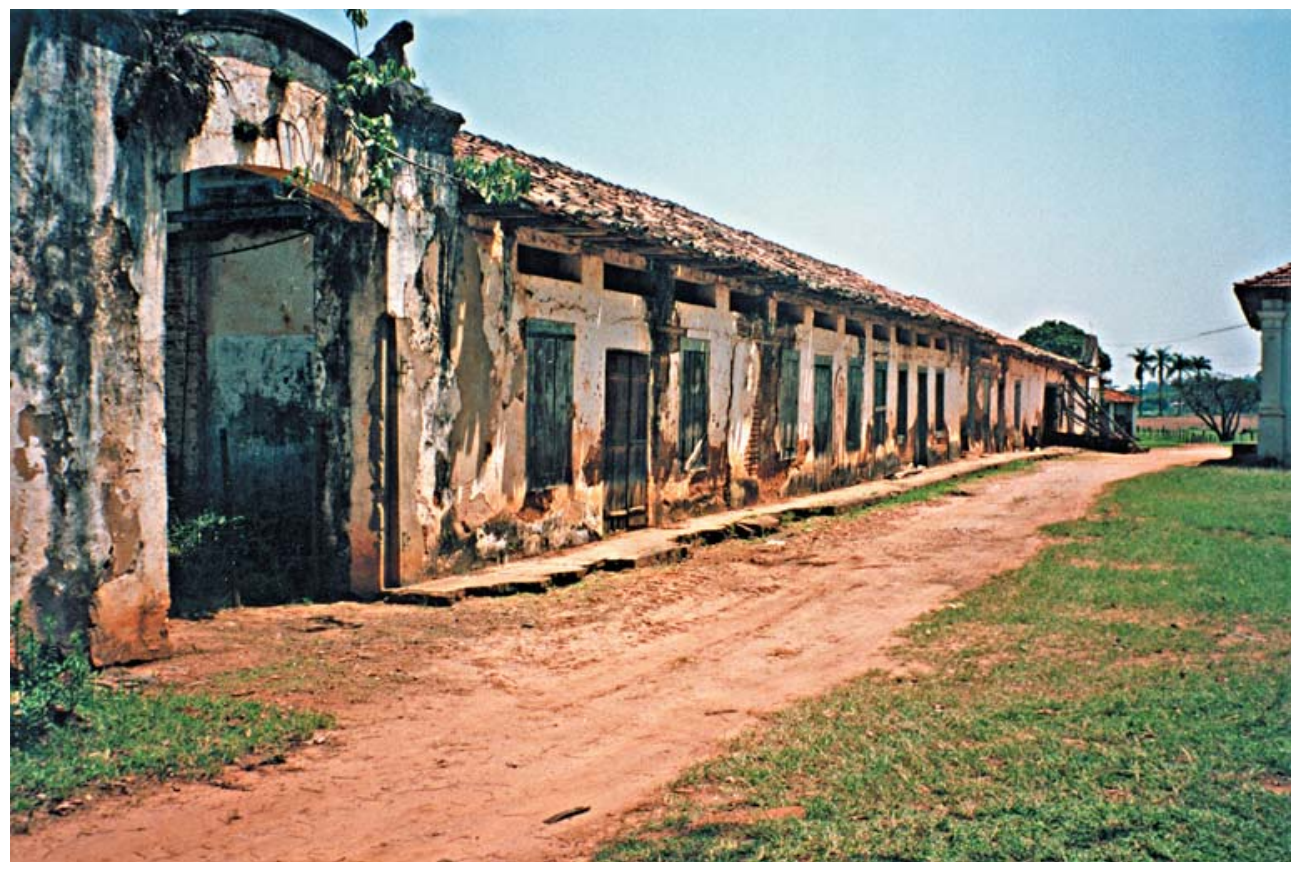

Figura 29 - Fazenda Pau d'Alho. Senzala da fazenda de café erguida na segunda metade do século XIX. Segmento da parede do curro onde ficava a porta de entrada. Erguida em taipa de pilão com divisórias em taipa de mão. Fotografias da equipe.

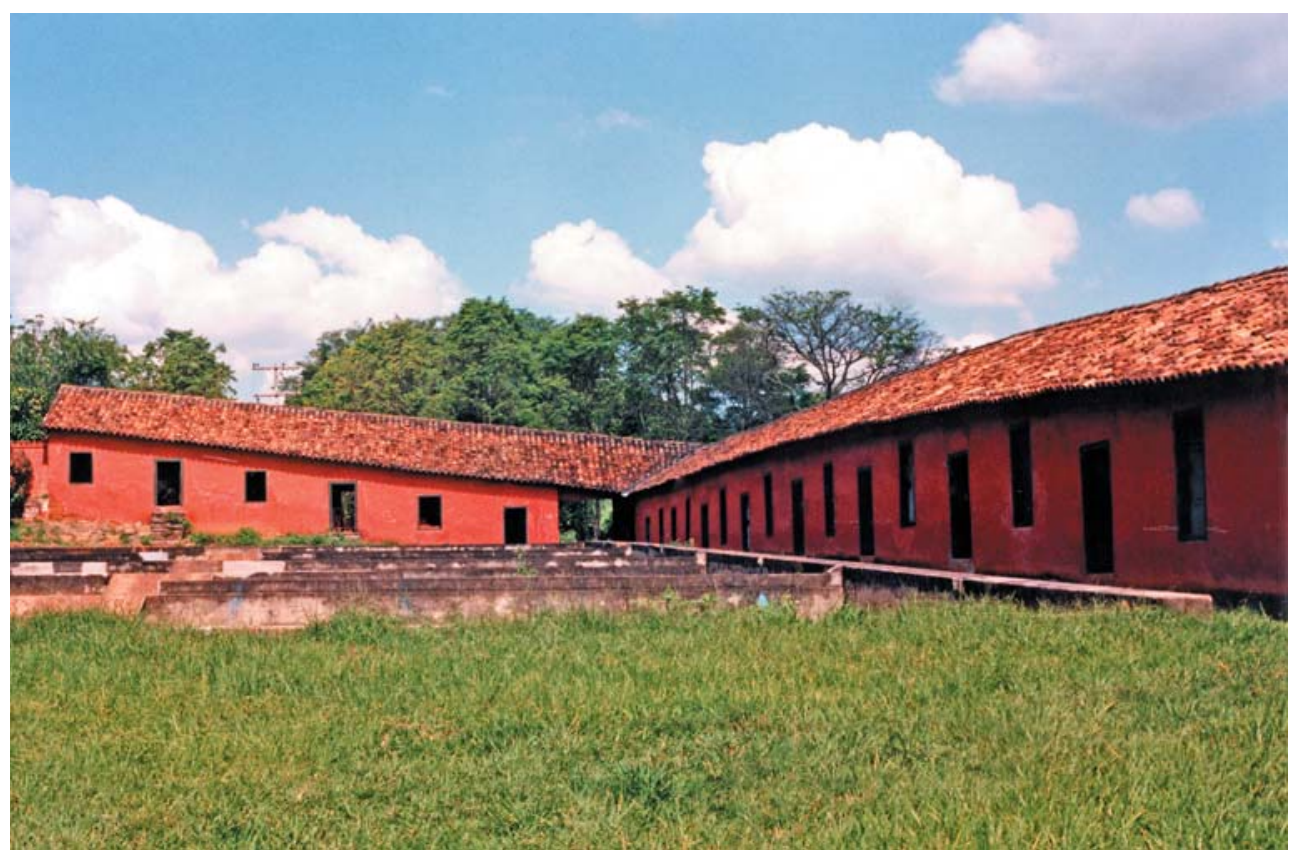

Figura 30 - Fazenda São Martinho. Do antigo curro da senzala lerguida na primeira metade do século XIX) conservam-se duas alas erguidas em paredes de taipa de pilão, sem divisórias internas. 
33. Centro de Memória da Unicamp - TJC, cx. 266, pasta 5225, Campinas.

34. Centro de Memória da Unicamp - TJC, cx. 292, pasta 5679; TJC, cx. 291, pasta 5664, Campinas. de Indaiatuba (1884), pioneiro na substituição do trabalho escravo pelo trabalho livre, ensaiada na Fazenda Sete Quedas em 1854, acham-se arrolados simultaneamente os dois espaços de moradia, dos negros e dos colonos: "um quadrado e duas colônias" ${ }^{\prime 3}$. Parece óbvio que, após a abolição da escravidão, os inventários passassem a registrar somente "casas de morada de colonos" (Fazenda Capoeira Grande, 1889; Fazenda Ribeirão, 1889-1993).34.

A preferência foi situar as colônias fora do contexto original da sede. Sem muito critério definido, elas foram implantadas em encosta, como nas fazendas Recreio, Bonfim, Iracema, Santana da Lapa, Sete Quedas (Fundação Bradesco), Capoeira Grande; sobre um terreno plano, a exemplo das fazendas Monte d'Este e Rio das Pedras; ov em áreas distantes da sede, como nas fazendas Rio das Pedras, Sete Quedas (distrito de Carlos Gomes), Roseira e Cabras. Alinham-se em grupos de casas, duas a duas ou em fileiras contínuas (fazendas Sete Quedas, Atibaia, Bonfim e Braga), quase sempre ritmadas por módulos tipo porta e janela. Todas erguidas em alvenaria de tijolos e cobertas com telha, capa e canal.

\section{REFERÊNCIAS}

ALINCOURT, L. d'. Memória sobre a viagem do porto de Santos à cidade de Cuiabá. São Paulo: Martins, 1953.

ANDRADE, A. L. D. de et al. Levantamento preliminar das fazendas. São Paulo: Condephaat, 1973.

Levantamento das técnicas e sistemas construtivos da região do Vale do Paraíba. São Paulo: Condephaat, 1976- , 15 vol.

ARAÚJO, E. et al. O café. São Paulo: Banco Real, 2000.

CAMILLO, E. E. R. Guia bistórico da indústria em Campinas (1850-1887). Campinas: Mercado de Letras; Centro de Memória da Unicamp, 1998.

CARRILHO, M. J. As fazendas de café do caminho novo da Piedade. 1994. Dissertação (Mestrado em Arquitetura e Urbanismo)-Faculdade de Arquitetura e Urbanismo, Universidade de São Paulo, São Paulo, 1994.

COSTA, L. Documentação necessária. In:TELLES,A. C. S. (Org.). Arquitetura civil II. São Paulo: MEC; Iphan; FAU-USP, 1975, p. 89-98.

FERRÃO,A. M. Arquitetura do café. Campinas: Editora da Unicamp; São Paulo:Imprensa Oficial do Estado de São Paulo, 2004.

HOLANDA, S. B. de. Raízes do Brasil. Rio de Janeiro: José Olympio, $7^{\text {a }}$ ed., 1973.

LEMOS, C.A. C. Cozinhas etc. São Paulo: Perspectiva, 1978. 
LEMOS, C.A. C. Alvenaria burguesa. São Paulo: Nobel, 1985.

Ramos de Azevedo e seu escritório. São Paulo: Pini, 1993.

Casa paulista. São Paulo: Edusp, 1999.

MARTINS,A. L. Império do café: a grande lavoura no Brasil de 1850 a 1890. São Paulo:Atual, 1990.

MARTINS, M.A.R. Um idealista realizador. Rio de Janeiro: Oficinas Gráficas doAlmanak Laemmert, 1939.

MATOS, O. N. de. Café e ferrovia. São Paulo:Alfa-Ômega, 1973.

MENDES, J. E. T. Lavoura cafeeira paulista (velhas fazendas do município de Campinas). Aquarelas de José de Castro Mendes. São Paulo: Departamento Estadual de Informações, 1947.

MILLIET, S. Roteiro do café e outros ensaios. São Paulo: Hucitec; INL, 1982.

MONTEIRO,A. M. R. G. Ramos de Azevedo: presença e atuação profissional. Campinas: 18791886. 2000. Dissertação (Mestrado em Urbanismo)-Faculdade de Arquitetura e Urbanismo, Pontifícia Universidade de Campinas, 2000.

PETRONE, M.T. S. A lavoura canavieira em São Paulo: expansão e declínio (1765-1851). São Paulo: Difusão Européia do Livro, 1968.

PUPO, C. M. M. Campinas, município do Império. São Paulo: Imprensa Oficial do Estado, 1983.

SAINT-HILAIRE,A. de. Viagem à Província de São Paulo. São Paulo: Martins, 1972.

SANTOS,A. C. Compra e venda de terras e águas e um Tombamento na primeira Sesmaria da Freguesia de Nossa Senhora da Conceição das Campinas do Mato Grosso de Jundiaí. 1998. Tese (Doutorado em Arquitetura e Urbanismo)-Faculdade de Arquitetura e Urbanismo, Universidade de São Paulo, 1998.

SEVCENKO, N.; MINDLIN, J. São Paulo de Edmund Pink. São Paulo: DBA, 2000.

STEIN, S. J. Grandeza e decadência do café no Vale do Paraíba. São Paulo: Brasiliense, 1961.

TAUNAY,A. d'E. História do café no Brasil. Rio de Janeiro: Departamento Nacional do Café, 1939.

TAUNAY, C.A. Manual do agricultor brasileiro. (1839). São Paulo: Companhia das Letras, 2001.

ZALUAR,A.A. E. Peregrinação pela Província de São Paulo (1860-1861). São Paulo: Itatiaia; Edusp, 1975.

Artigo apresentado em 06/2005. Aprovado em 03/2006. 